\title{
التضمين التربوي لمعاني لفظ "القلب" في القرآن الكريم
}

\author{
ديديه وحى الدين \\ نساء فطري علمياواتي \\ جامعة سونان غونونج جاتي الإسلامية الحكومية باندونج \\ Email:nifil92@gmail.com
}

\begin{abstract}
ملخص ملن

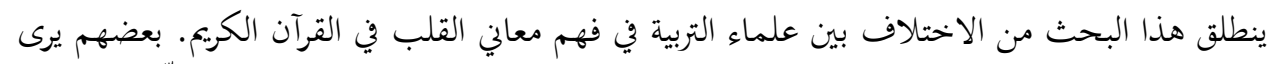

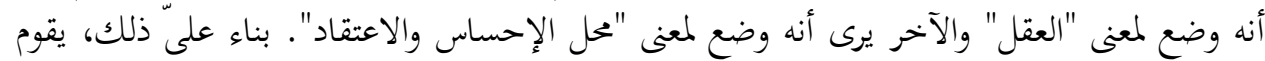

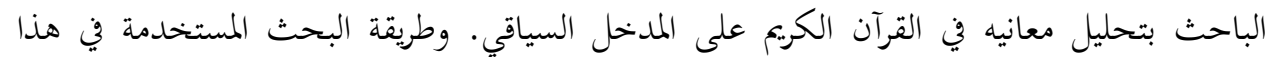

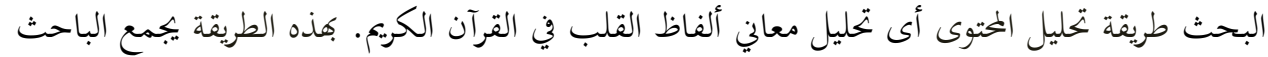

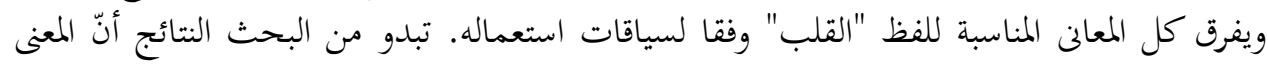

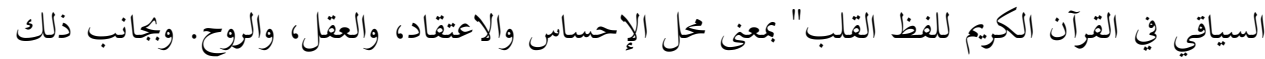

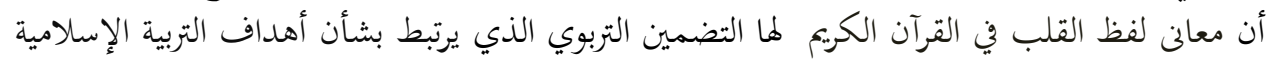

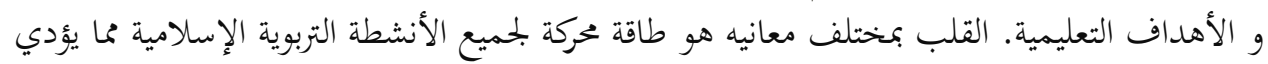
إلى حضارة إنسانية متقدمة. المصطلحات الرئيسية: القلب، المدنخل السياقي، التضمين التربوي
\end{abstract}

\section{ABSTRACT}

Based on the contradiction among educational experts in interpreting the word al-qalb on the Holy Quran. Most interpret the "mind" and others interpreted with "beart" as there is no common word. On that basis, this study aimed to dissect the meaning of al-qalb on the Holy Qur'an with semantic approach. The method used in this study is a content analysis. The method is appropriate for the aspect of sentence context surrounding the word al-qalb in a variety of verses and letters. From the results of the study concluded that the word al-qalb on the Holy Qur'an contains three meanings: 1) the place of faith and emosion ; 2 ) mind, and 3 ) the spirit or lives. Thus, the contradiction among educational experts can actually be met within the context of the sentence in the Holy Qur'an. This also has implications for understanding the cognitive aspects of education, especially coaching (sense) and spiritual aspects (faith).

Keywords: Al-qalb, Semantics Approach, Educational Implications 
Dedih Wahyudin dan Nisa Fitri Ilmiawati

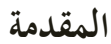

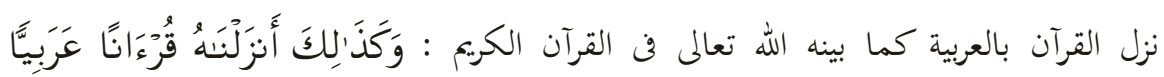

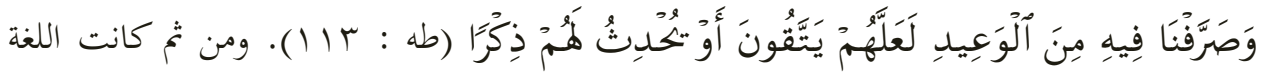

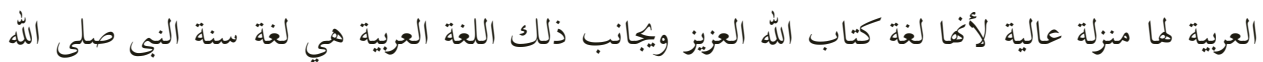

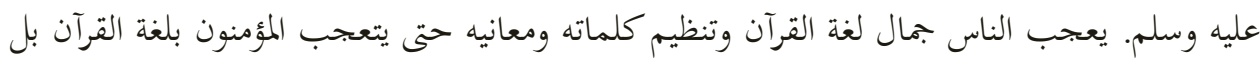

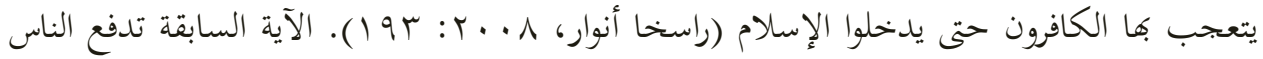

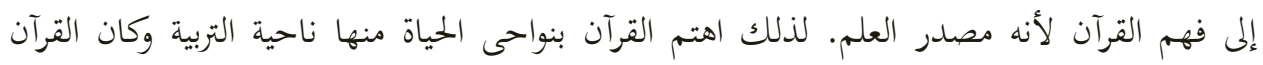

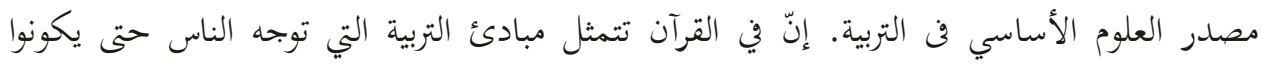
متكاملين في حياةم.

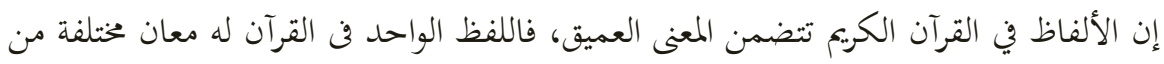

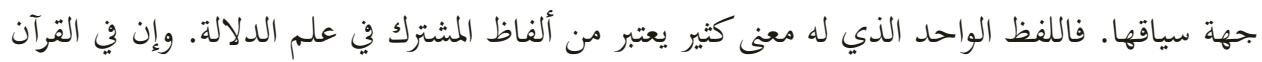

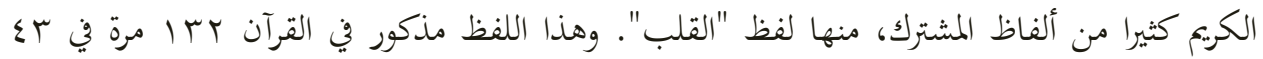

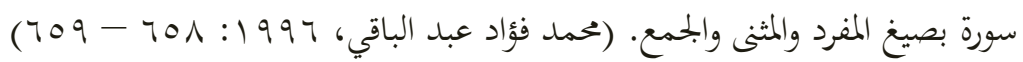

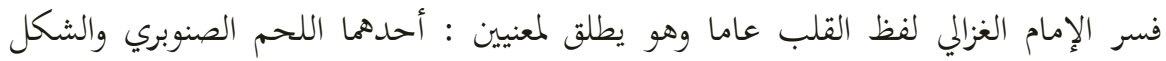

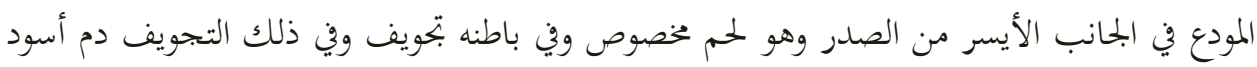

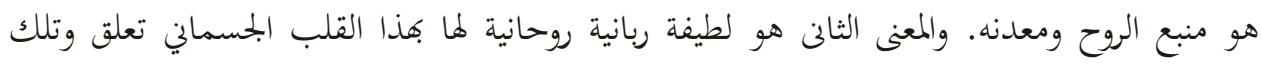

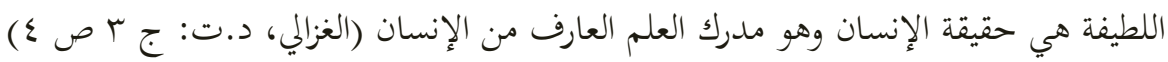

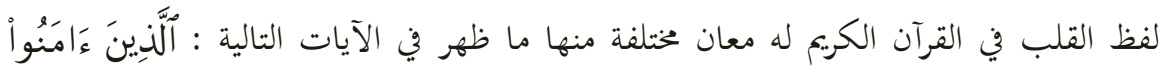

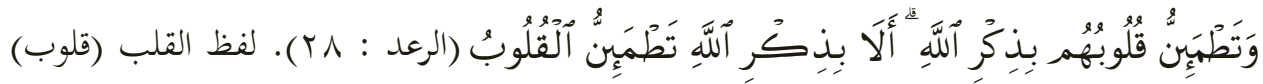

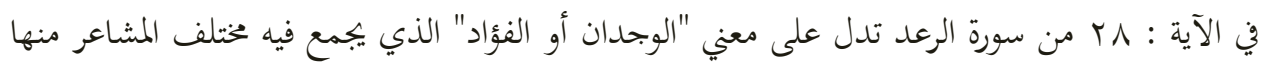

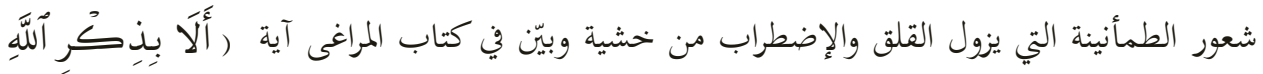

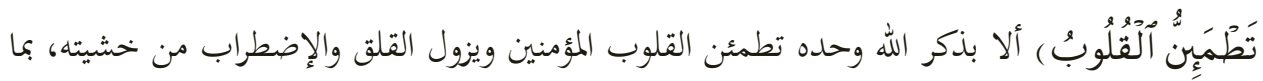

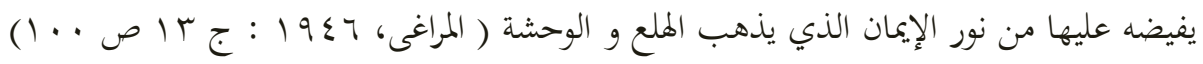

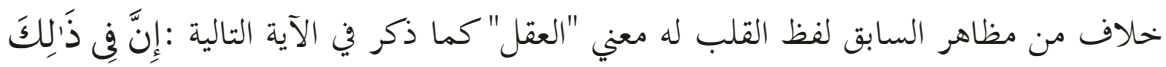

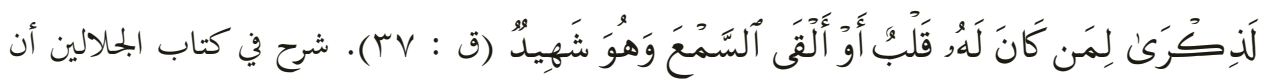

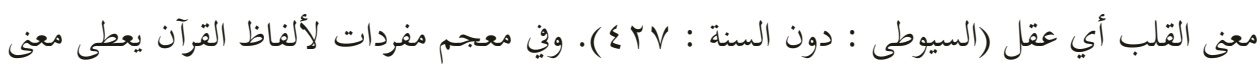




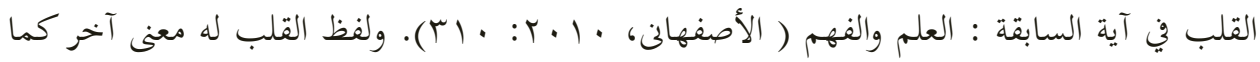

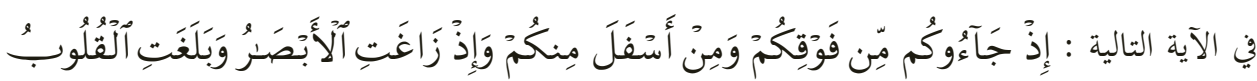

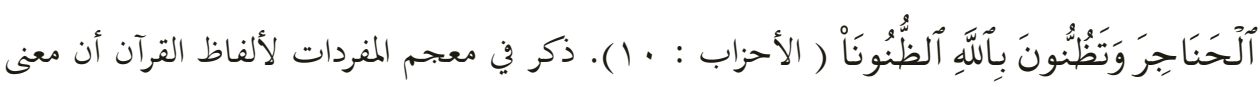

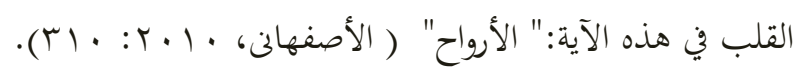

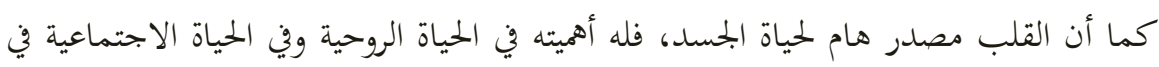

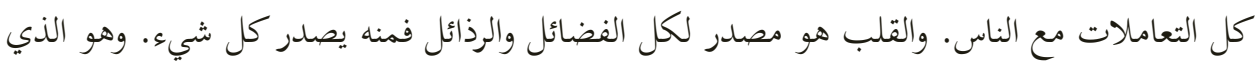

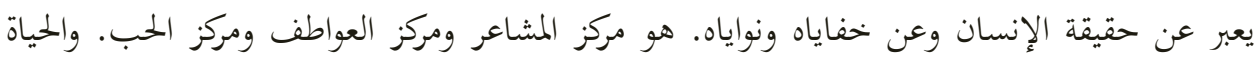

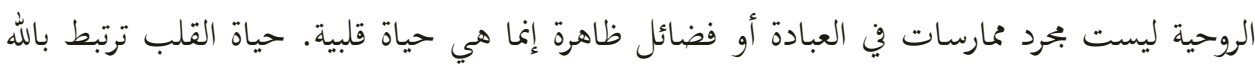

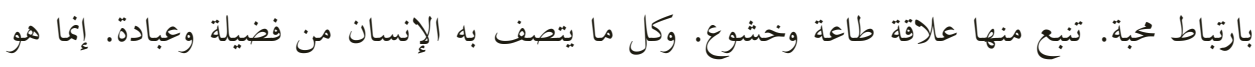
نابع من قلبه، ومن حب هذا القلب للخير. بالنسبة إلى أن التربية الروحية تتضمن عدة الفيب ليجر، حدود ومنها العلاقة المتبادلة بين القلب، والنفس،

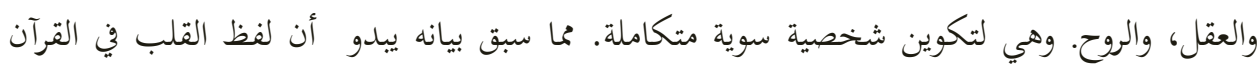

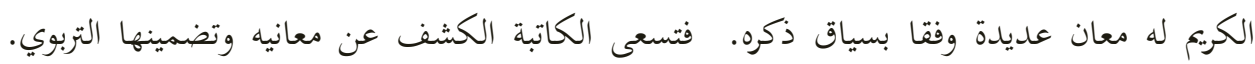

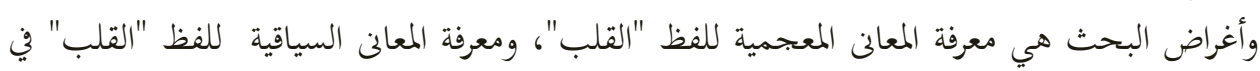

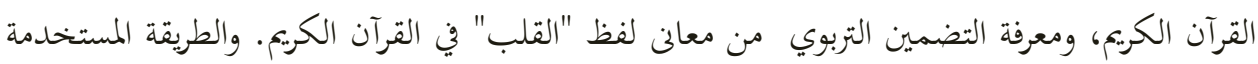
في هذا البحث هي طريقة تحليل المحتوى (content analysis) لدراسة معنى لفظ القلب فئل في القرآن الكريع.

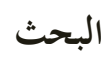

أهمية الدلالة - مالة

إن لعلم الدلالة مكانة خاصة بين فروع علم اللغة فأهمية الدلالة تزيد يوما بعد يوم في عصرنا

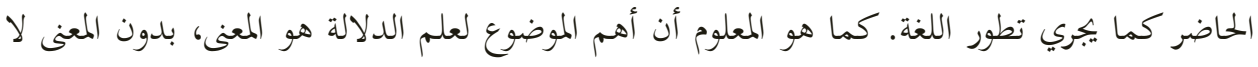

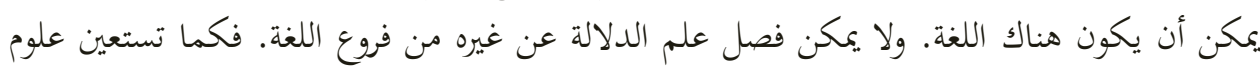

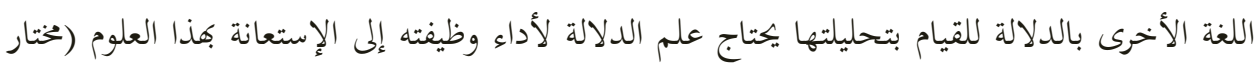
عمر، 1994 : ب 1).

تتنوع الدلالات بتنوع مستويات الدرس اللغوى، وبتنوع سمات النظام الرمزى اللغوى. ومن هنا

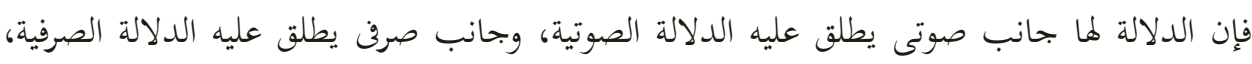

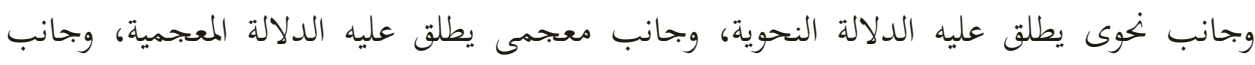

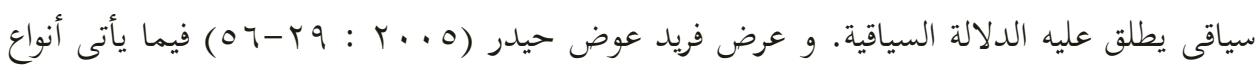

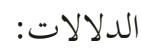


Dedih Wahyudin dan Nisa Fitri Ilmiawati

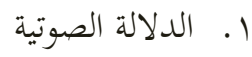

المراد بها، تلك الدلالة المستمدة من طبيعة بعض الأصوات. أى إذا تغيّر الصوت تغيّر معنى. نحو: الخضم والقضم، فالخضم لأكل الرطب كالبطيخ والقثاء، و القضم للصلب اليابس. r. (ب الدلالة الصرفية

وهي تلك الدلالة التى يعرب عنها مبنى الكلمة. مثلا كلمة "مدرّس" يدل على معنى معلم،

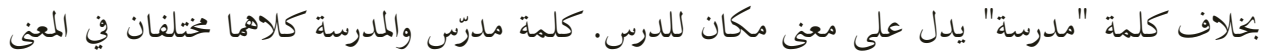
ولو كانا من أصل واحد وهو "درس". ب. الد الالة النحوية

وهي الدلالة المحصلة من استخدام الألفاظ أو الصور الكلامية في الجملة المكتوبة، أو المنطوقة على المستوى التحليلى أو التركيى. مثلا عندنا جملتان، الجملة الأولى: رأى عليٌ الولدَ والجملة الثانية: رأى عليًا الولدُ. كان المعنى من الجملة الأولى هو "علي رأى الولد" لأن لفظ علي يكون فاعلا و لفظ

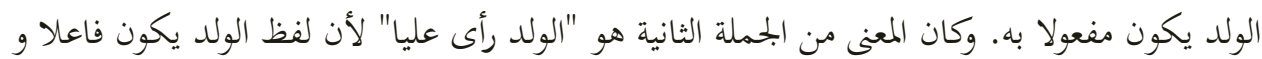
لفظ علي يكون مفعولا به.

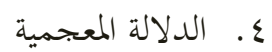

وهي دلالة الكلمات المكتوبة في القاموس وهي الدلالة الأصلية أو الأساسية بالوضع اللغوي. مثلا إذا أردنا أن نبحث عن معنى الكلمة "كرسي" في المعجم فمعناه مكان للجلوس.

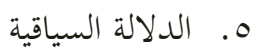

وهي الدلالة التى يعينها السياق اللغوى وهو البيئة اللغوية التى تحيط بالكلمة أو العبارة أو الجملة.فعندما نضع كلمة التوليد مثلا في السياقات الثلاثة الآتية: ا. إن التوليد من أهم عوامل النمو اللغوى (المتحدث هنا لغوى). يعنى توليد الألفاظ ومعان جديدة، تؤدى إلى ثراء اللغة. r. إن التوليد من المهام الإنسانية الصعبة (المتحدث هنا طبيب). وفي هذا السياق يدل على مهمة توليد الأطفال.

r. إن التوليد يعد أهم عوامل استمرار التيار (المتحدث هنا المهندس كهرباء). وفي هذا السياق يدل على إنتاج الطاقة الكهربائية بواسطة أجهزة معينة.

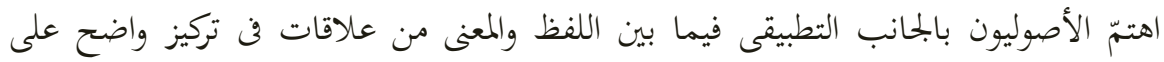
مدلولات العبارات لاستخراج الأحكام الشرعية وتطبيقها. فاللغويون قد نظروا إلى الألفاظ من زوايا متعددة، حيث الغة بمناثبة الكنز بين أيديهم فلا بد من اعادته وكانت عنايتهم شديدة بيبان أصول 
الألفاظ وميزوا بين اللفظ الذى تعددت ألفاظه واللفظ وضده. ومن اللفظ الذى تعددت معانيه في علم

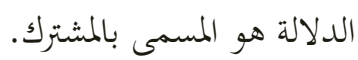

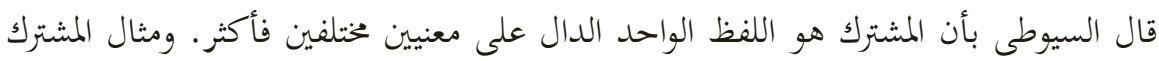

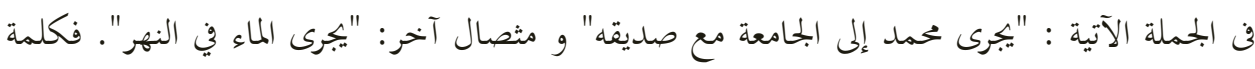

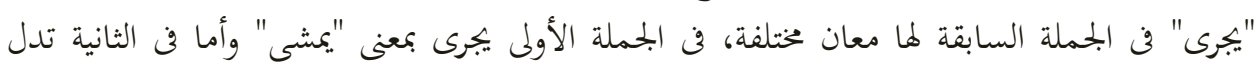
على معنى "يسيل".

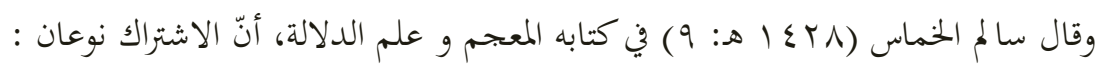

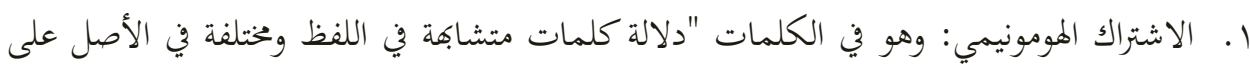
معان مختلفة" ومن أمثلته في الكلمات المفردة:

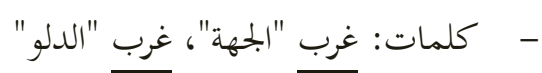

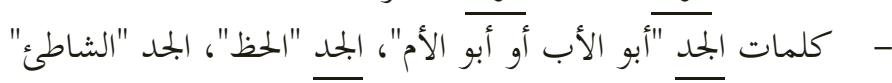

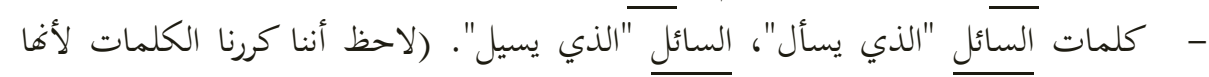

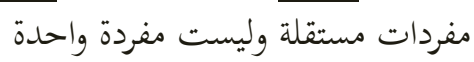

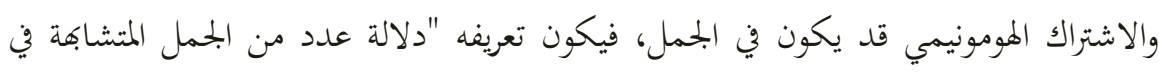

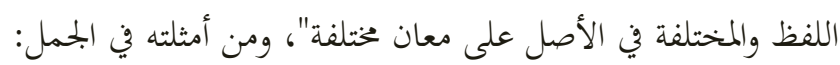

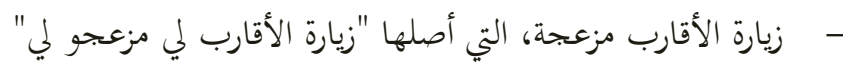

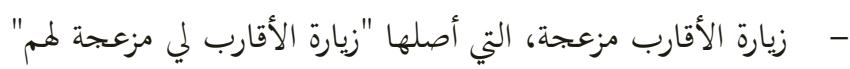

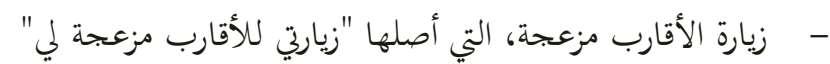

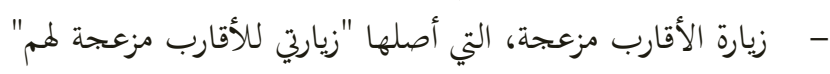

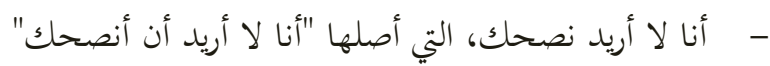

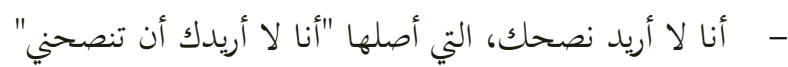

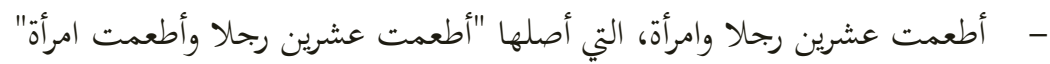

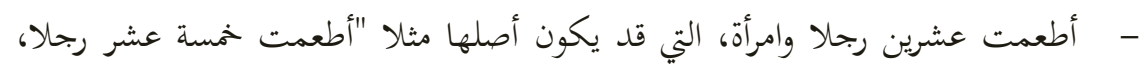
وأطعمت خمس نساء" أطعمت عثرين رجالا وارئ - أطعمت عشرين رجلا وامرأة، التي قد يكون أصلها مثلا "أطعمت عشرين رجلا،

$$
\text { وأطعمت عشرين امرأة" }
$$

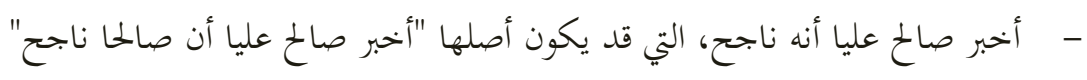

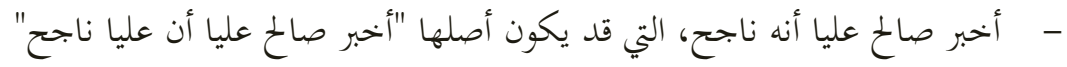




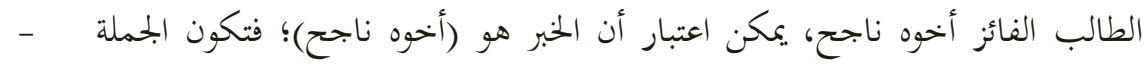

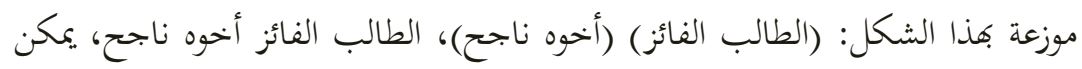
اعتبار أن الخبر هو (ناجح)؛ فتكون الجملة موزعة بهذا الشكل: (الطالب الفائز أخوه) (ناج)

r. الاشتراك البوليسيمي:

تعريفه في المفردات: هو دلالة كلمة واحدة على معان مختلفة تربطها علاقة دلالية، مثل:

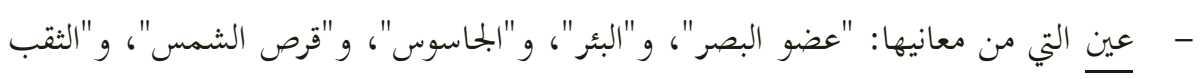

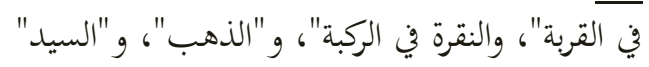

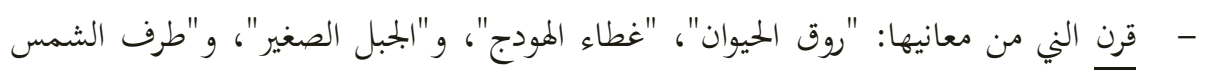

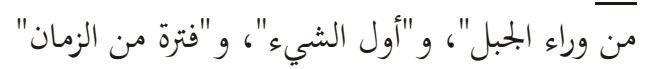

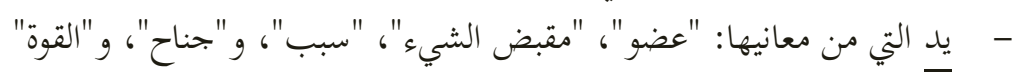
وتعريف الاشتراك الواقع في الجمل والتراكيب يكون على النحو التالي: "دلالة جملة واحدة على

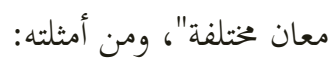
- قوله - صلى الله عليه وسلم - لنسائه قبيل وفاته "أسرعكنّ لحاقا بي أطولكنّ يدا". ومما يدل

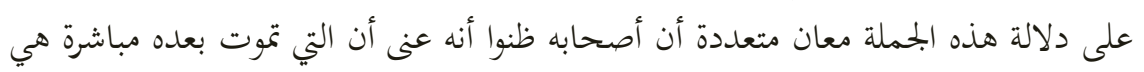
عائشة _رضي الله عنها- لأها كانت طويلة اليدين، ولكنه في الواقع كان يعني زينب لأهما

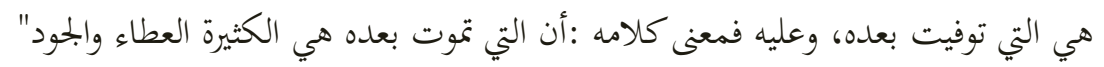

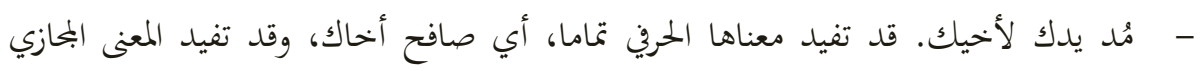
"ساعد أخحاك" - متحم العقبة. هذه الجملة قد تفيد معنى حرفيا "اصعد المكان العالي من الجبل"، وقد تفيد

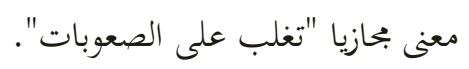

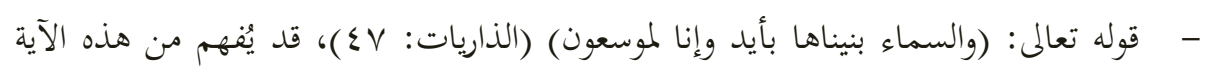

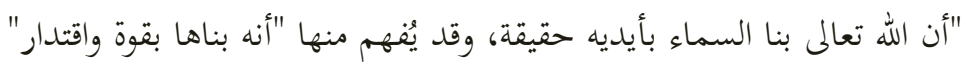

\section{الآيات المشتملة على لفظ القلب في القرآن الكريم}

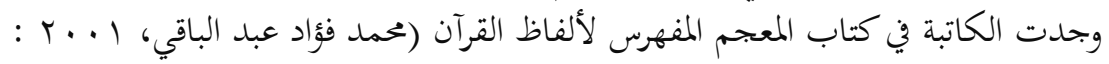

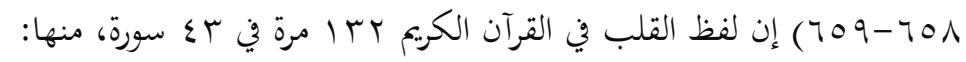

\begin{tabular}{|c|c|c|}
\hline آيات & سورة و آية & رقم \\
\hline 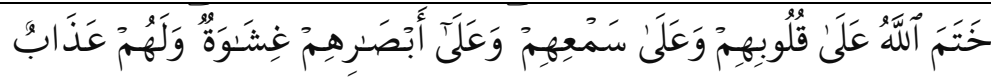 & V : البقرة & 1 \\
\hline
\end{tabular}




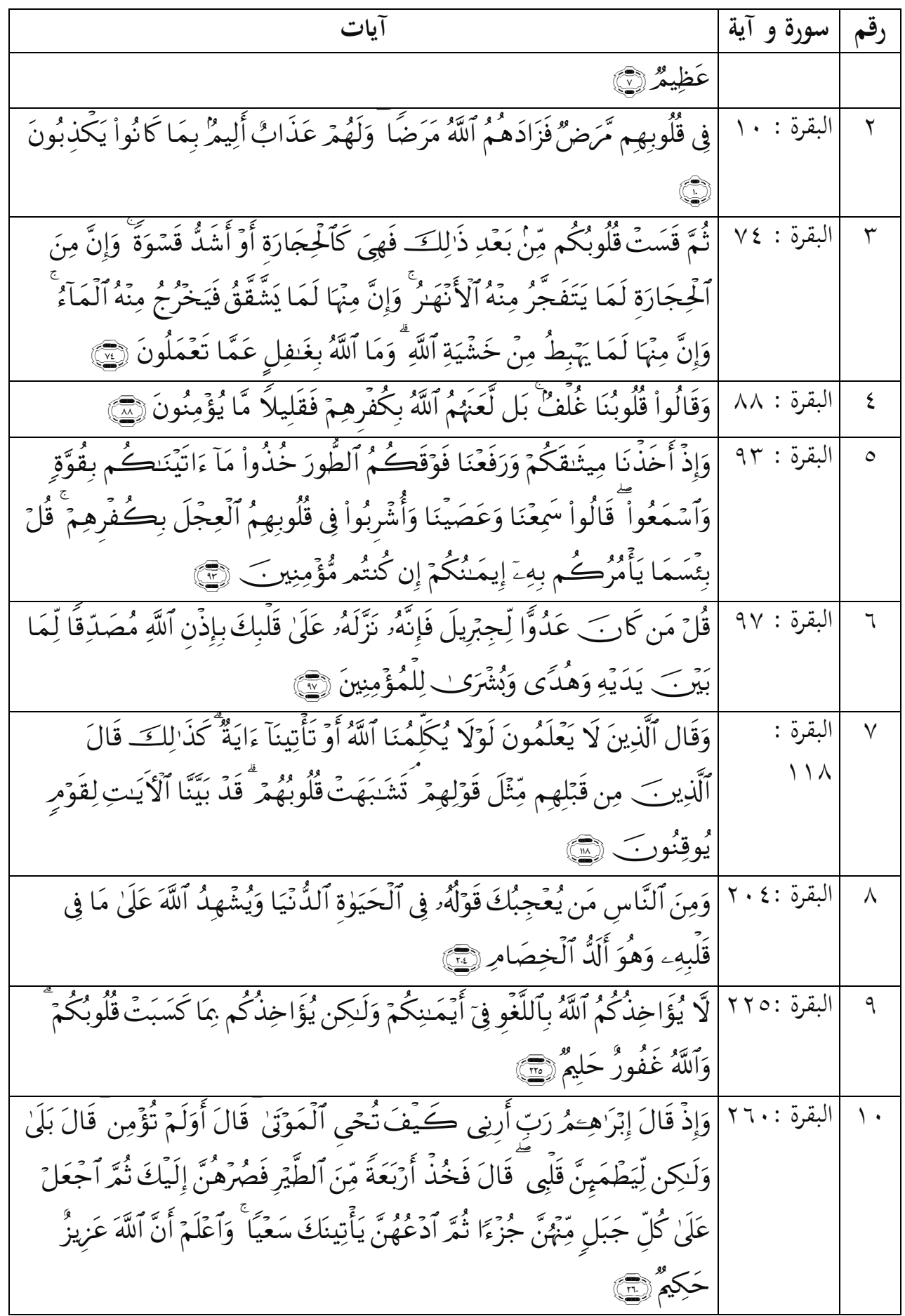




\begin{tabular}{|c|c|c|}
\hline & سورة و آية & رقم \\
\hline 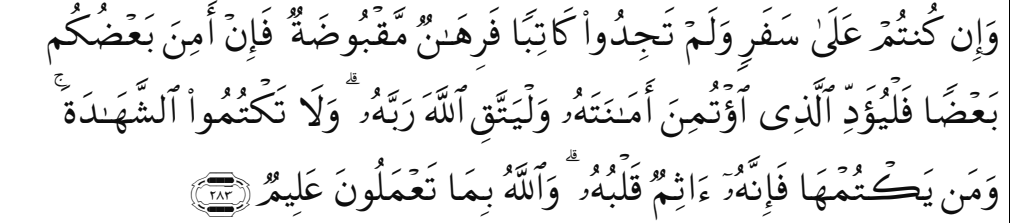 & البقرة : & 11 \\
\hline 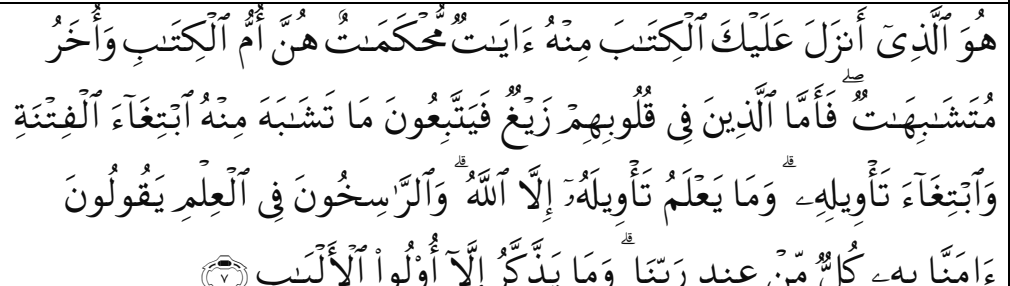 & 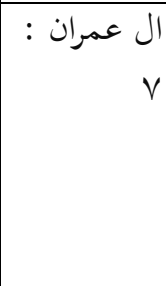 & $1 \%$ \\
\hline 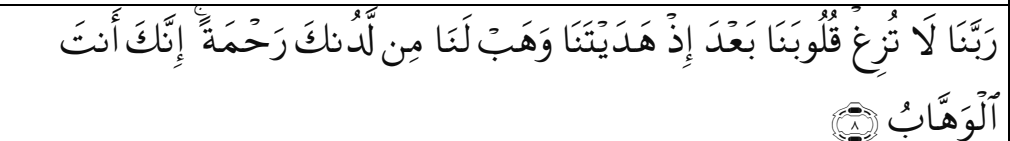 & ال عمران : & 11 \\
\hline 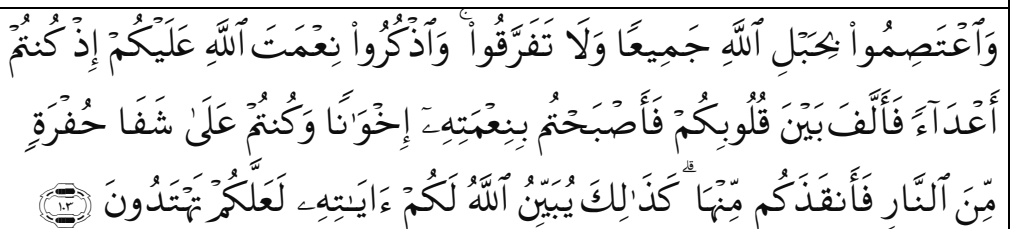 & 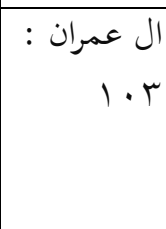 & $1 \varepsilon$ \\
\hline 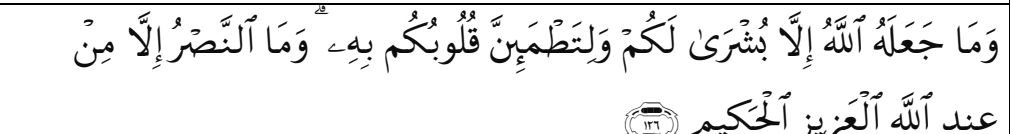 & 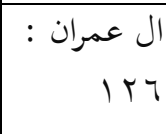 & 10 \\
\hline 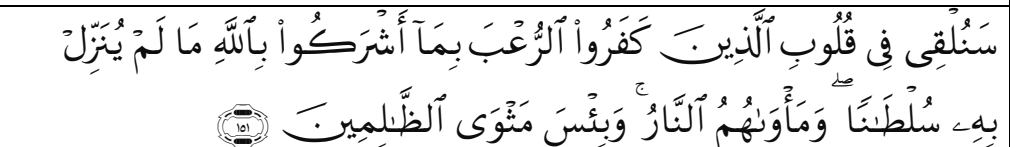 & 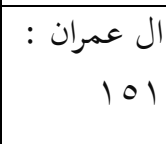 & 17 \\
\hline 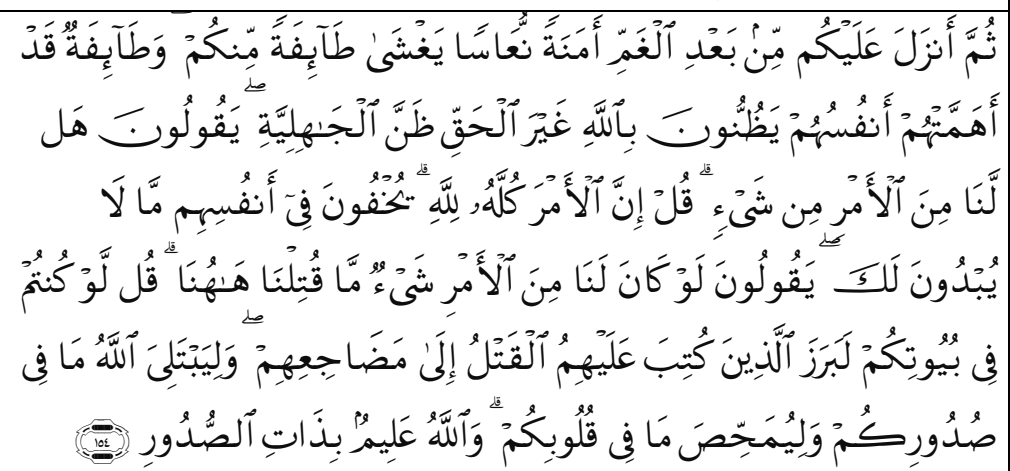 & 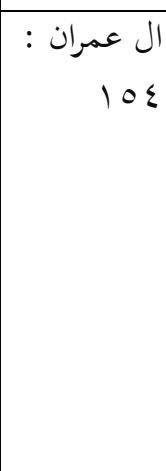 & $1 \mathrm{~V}$ \\
\hline 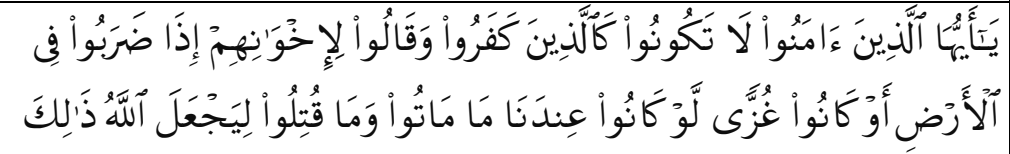 & $\begin{array}{r}\text { ال عمران } \\
\text { ان } 10\end{array}$ & 11 \\
\hline
\end{tabular}




\begin{tabular}{|c|c|c|}
\hline آيات & سورة و آية & رقم \\
\hline 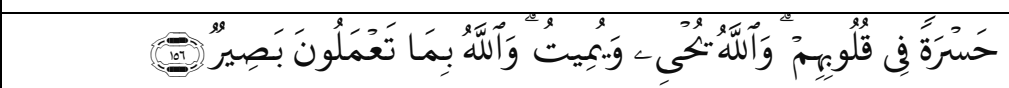 & & \\
\hline 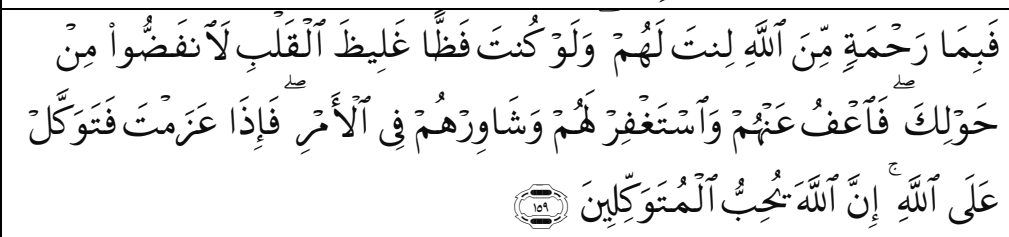 & $\begin{array}{r}\text { ال عمران } 109 \\
\text { : } 109\end{array}$ & 19 \\
\hline 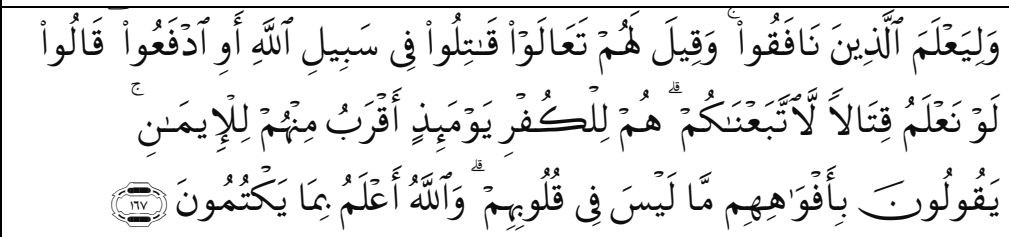 & 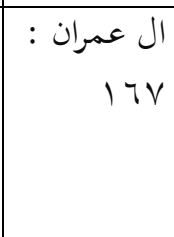 & $r$. \\
\hline 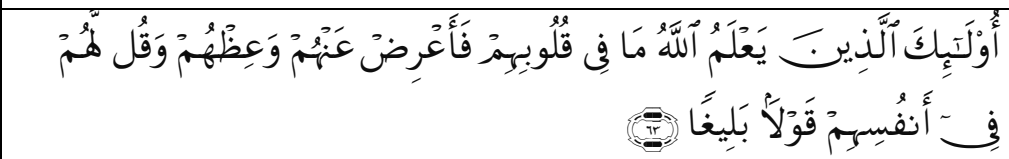 & "النساء : & $r_{1}$ \\
\hline 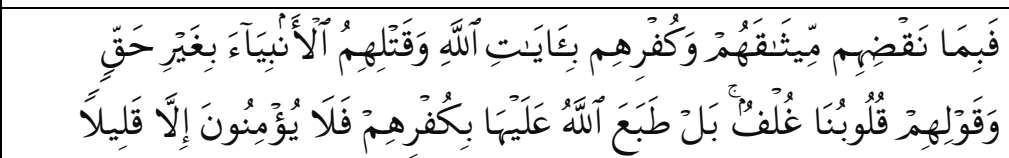 & $\begin{array}{r}\text { : النساء } \\
100\end{array}$ & Tr \\
\hline & & \\
\hline 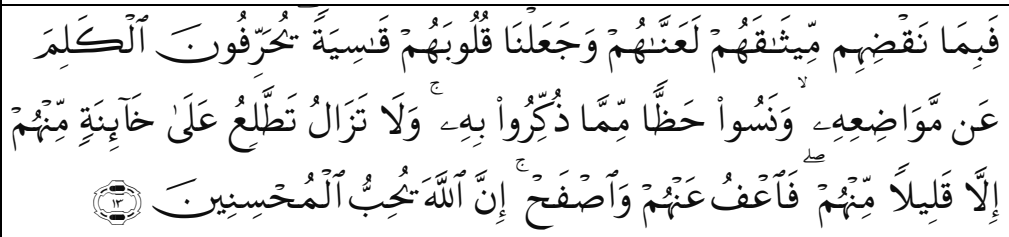 & المائدة : $1 \%$ & $r \mu$ \\
\hline 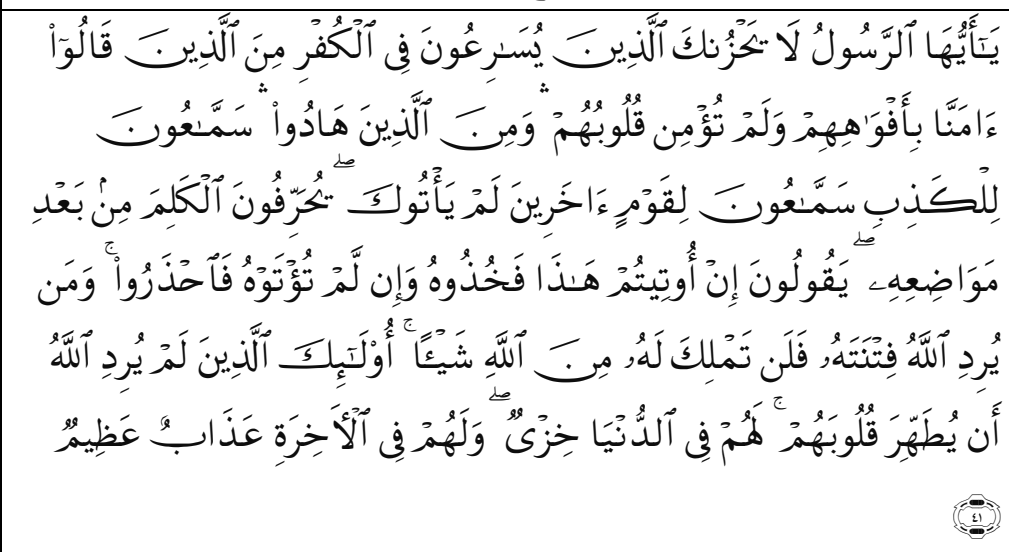 & المائدة : 1 & $r \varepsilon$ \\
\hline 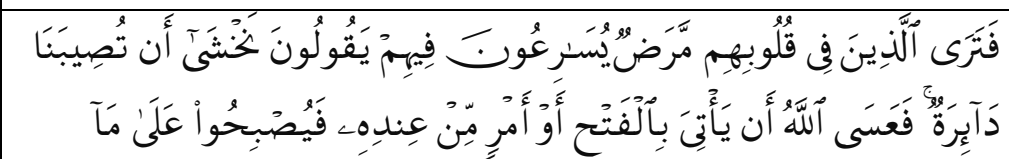 & المائدة : & ro \\
\hline
\end{tabular}


Dedih Wahyudin dan Nisa Fitri Ilmiawati

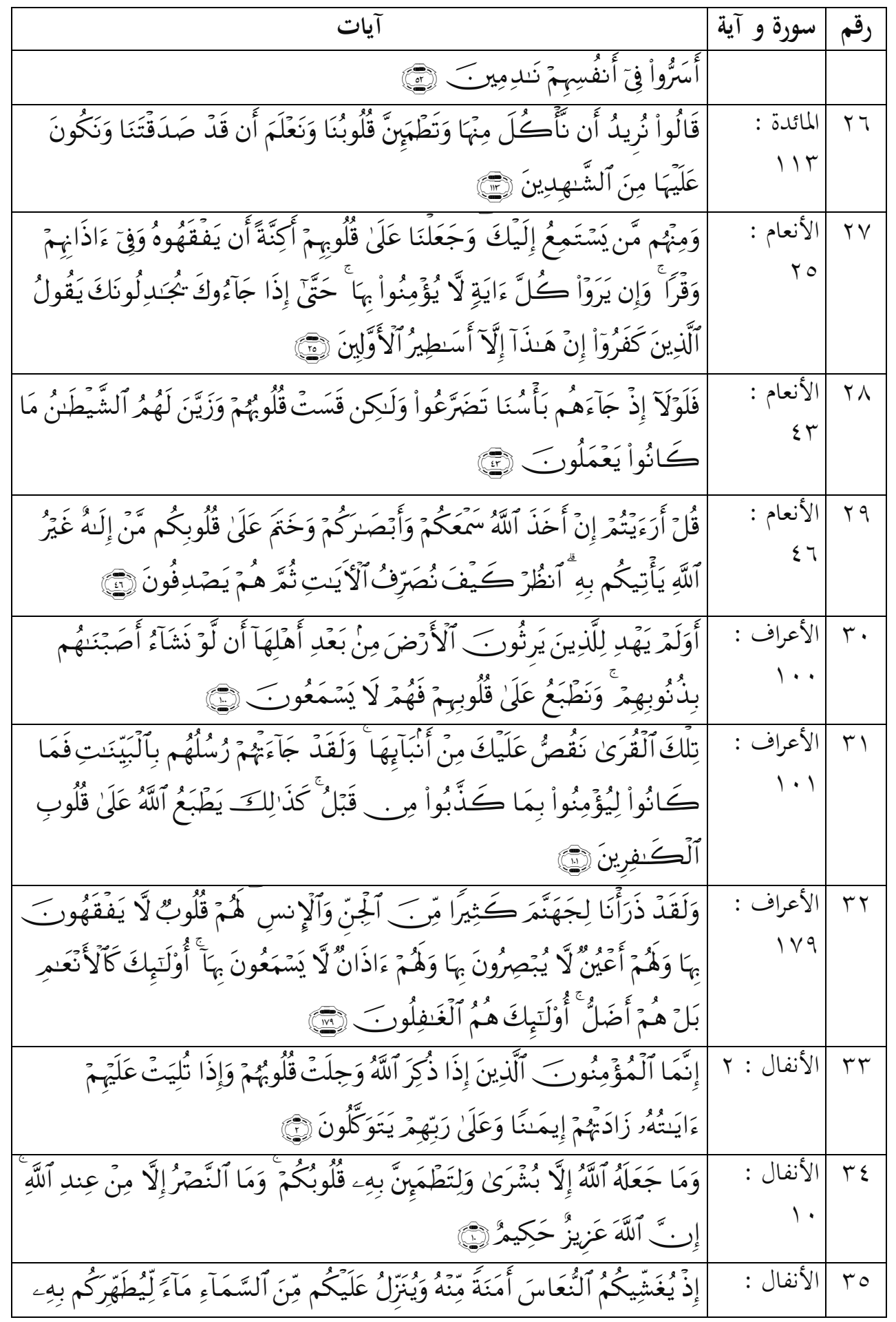




\begin{tabular}{|c|c|c|}
\hline آيات & سورة و آية & رقم \\
\hline 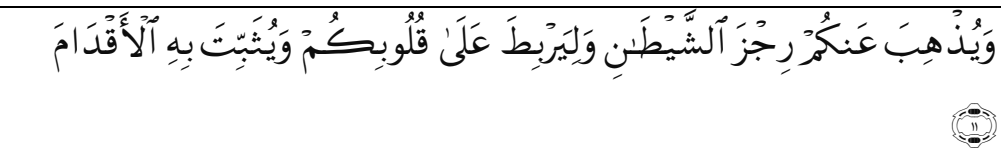 & 11 & \\
\hline 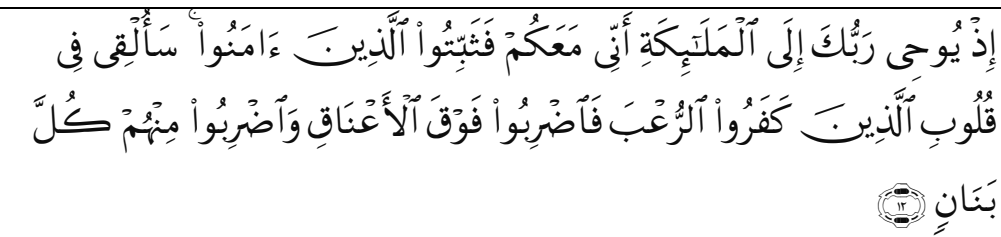 & $\begin{aligned} \text { الأنفال } \\
\text { ال }\end{aligned}$ & $r_{4}$ \\
\hline 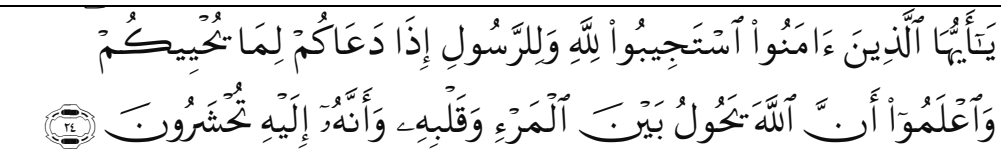 & الأنفال & $r v$ \\
\hline 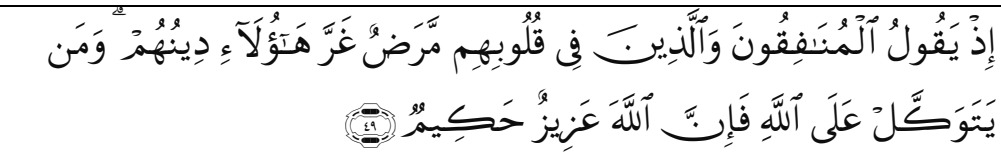 & $\begin{array}{r}\text { الأنفال } \\
\text { 9 }\end{array}$ & $\mu_{\Lambda}$ \\
\hline 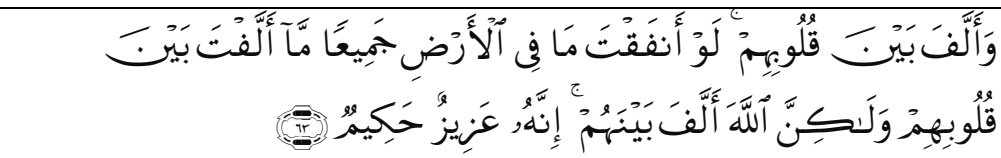 & الأنفال & rq \\
\hline 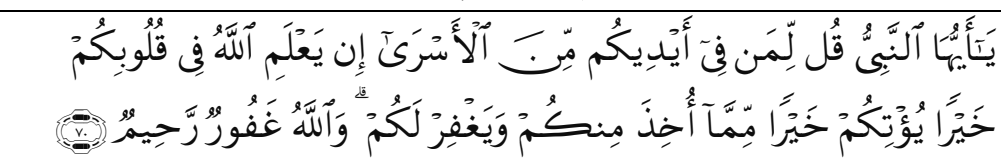 & $\begin{array}{c}\text { الأنفال } \\
\text { • }\end{array}$ & $\varepsilon$. \\
\hline 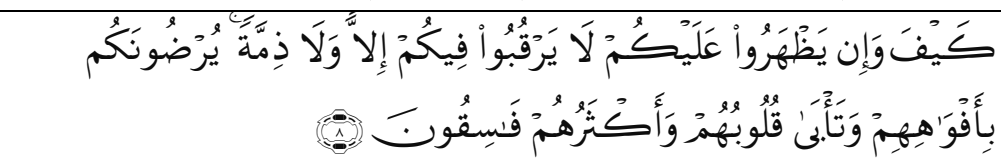 & التوبة : 1 & $\leqslant 1$ \\
\hline 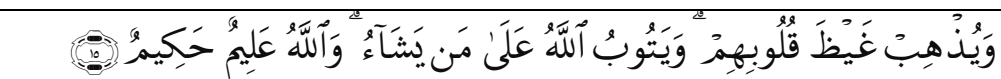 & التوبة : 10 & $\varepsilon r$ \\
\hline 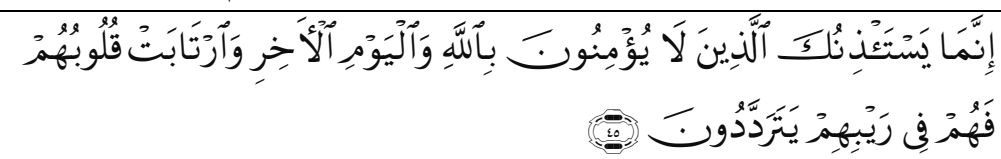 & التوبة : 0؛ & $\varepsilon r$ \\
\hline 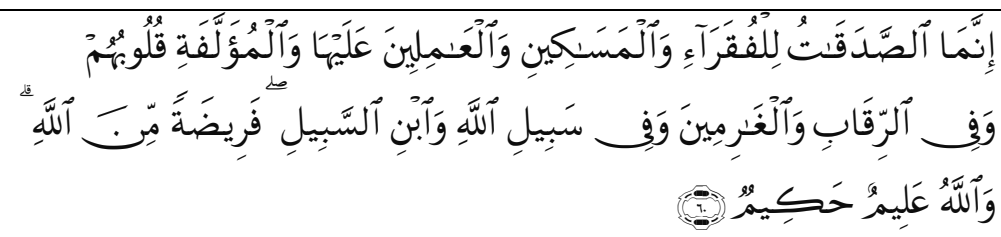 & التوبة : • & $\varepsilon \varepsilon$ \\
\hline 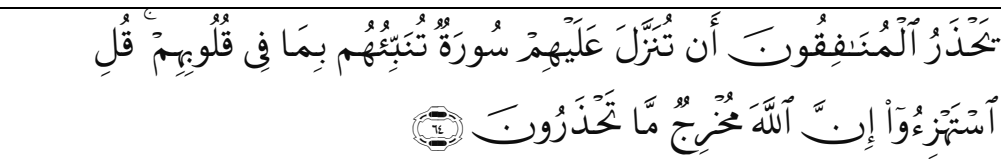 & التوبة : ع 17 & $\varepsilon 0$ \\
\hline
\end{tabular}




\begin{tabular}{|c|c|c|}
\hline آيات & سورة و آية & رقم \\
\hline 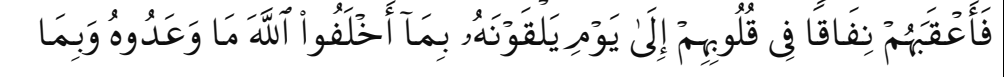 & VV : التوبة VV & $\varepsilon 7$ \\
\hline 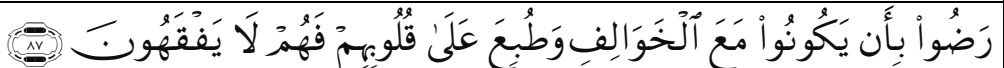 & 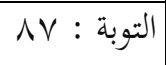 & $\varepsilon V$ \\
\hline 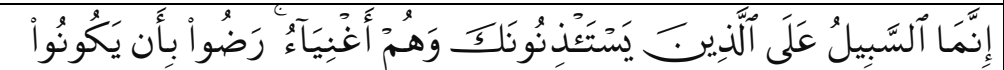 & 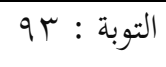 & $\varepsilon \wedge$ \\
\hline 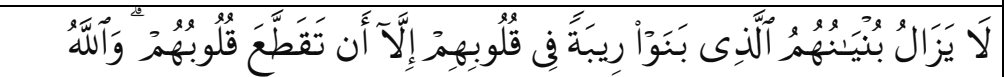 & 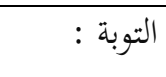 & $\varepsilon q$ \\
\hline 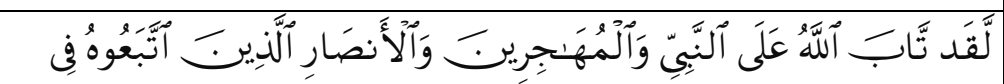 & & 0. \\
\hline 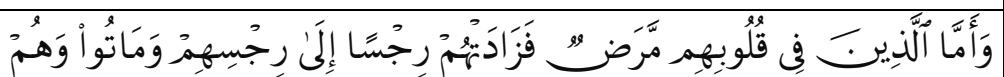 & التوبة : & 01 \\
\hline 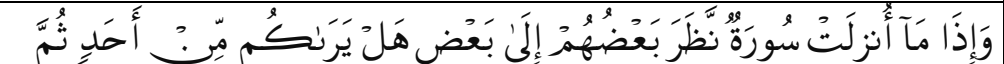 & 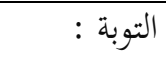 & Or \\
\hline 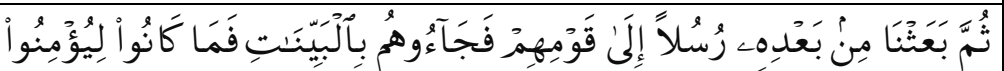 & يونس : ع V & or \\
\hline 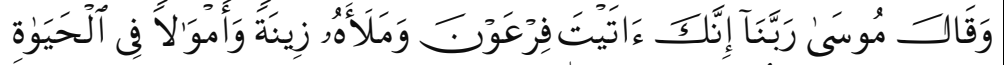 & يونس : يو & $0 \leqslant$ \\
\hline 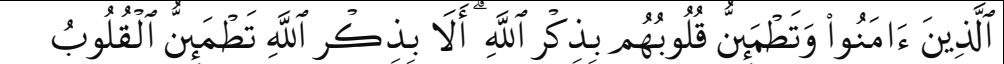 & 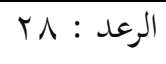 & 00 \\
\hline & الحجر & 07 \\
\hline 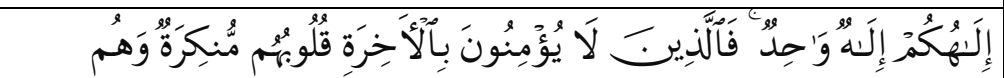 & النحل & OV \\
\hline
\end{tabular}




\begin{tabular}{|c|c|c|}
\hline آيات & سورة و آية & رقم \\
\hline 포 & $T Y$ & \\
\hline 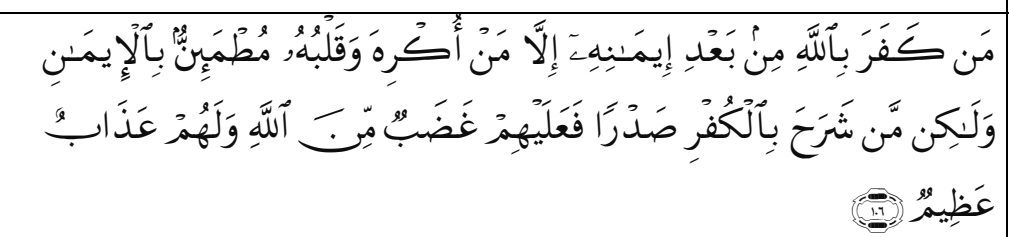 & ال النحل : & 01 \\
\hline 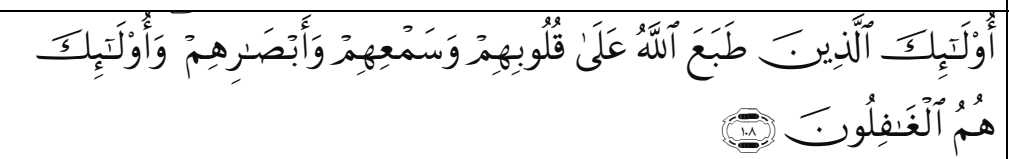 & 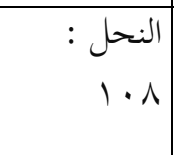 & 09 \\
\hline 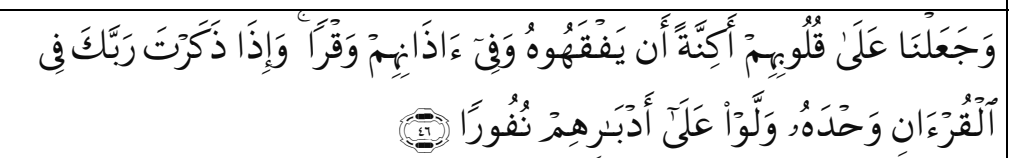 & الإسراء : & 7. \\
\hline 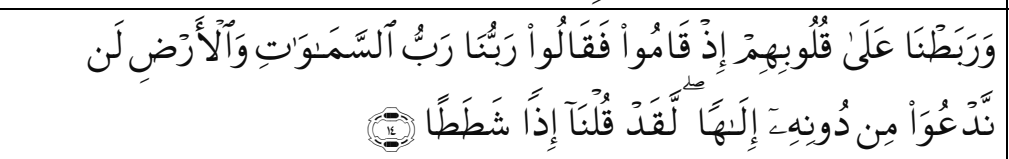 & الكهف : & 71 \\
\hline 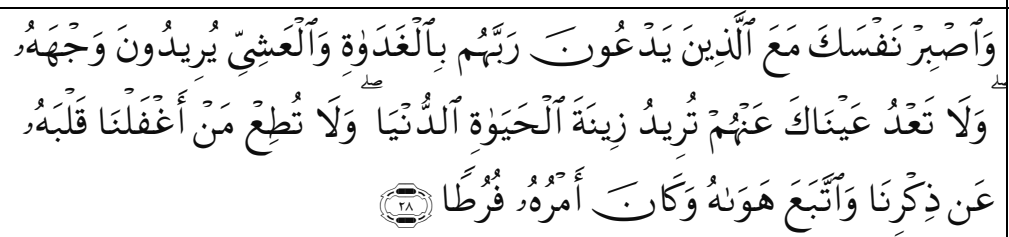 & الكهف : & Tr \\
\hline 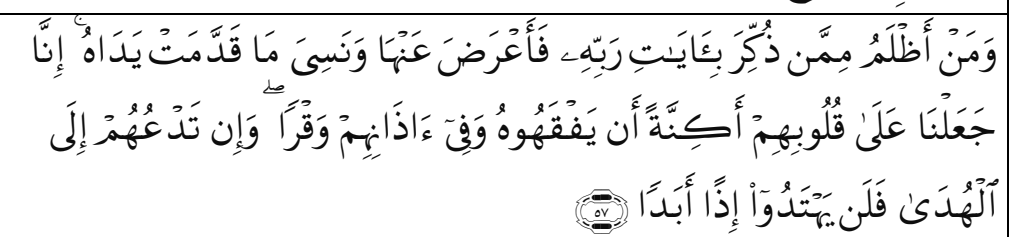 & 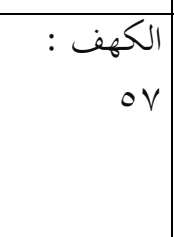 & $7 \pi$ \\
\hline 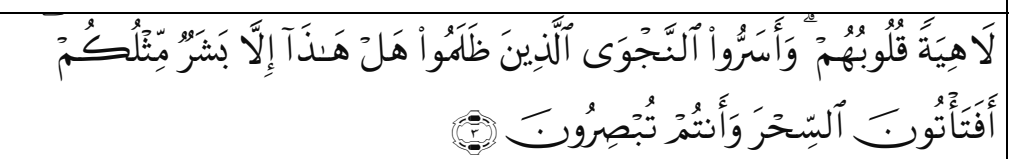 & الأنبياء : & $7 \varepsilon$ \\
\hline 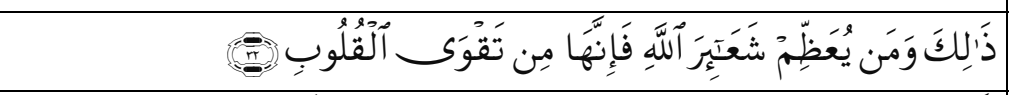 & 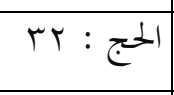 & 70 \\
\hline 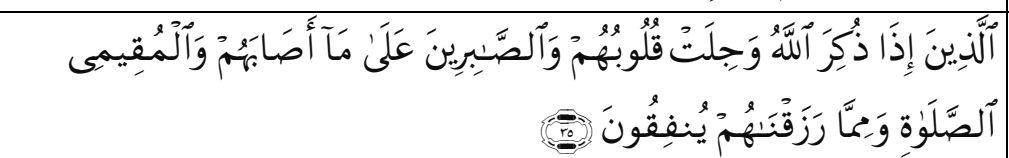 & ro: الحج & 77 \\
\hline 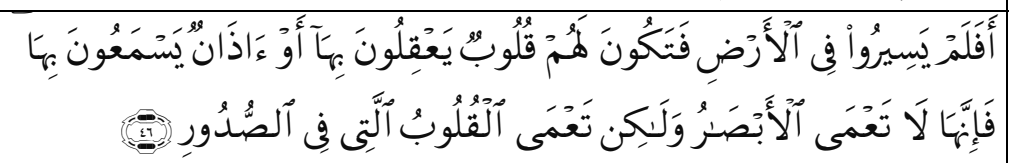 & ؛7: الحج & TV \\
\hline
\end{tabular}




\begin{tabular}{|c|c|c|}
\hline$ت$ & 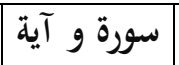 & رقم \\
\hline 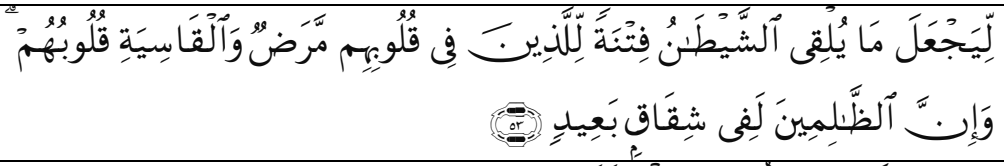 & 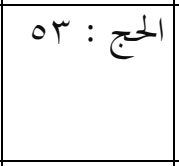 & 71 \\
\hline 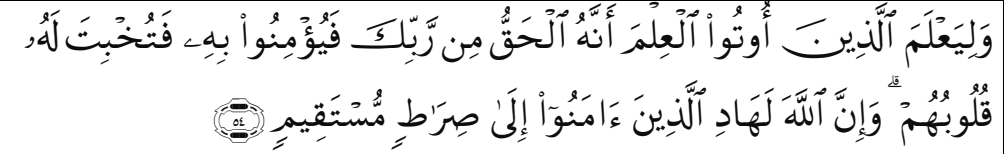 & 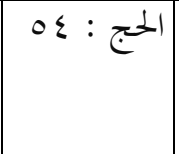 & 79 \\
\hline 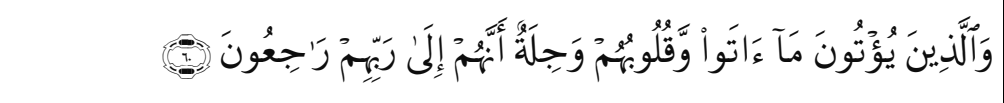 & 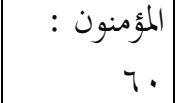 & $V \cdot$ \\
\hline 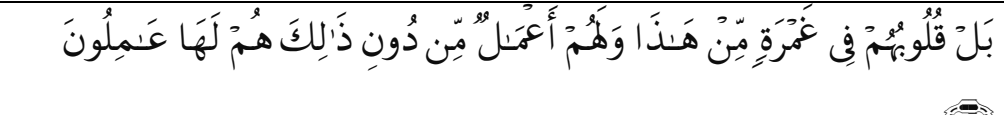 & 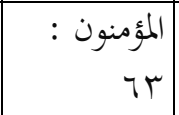 & VI \\
\hline 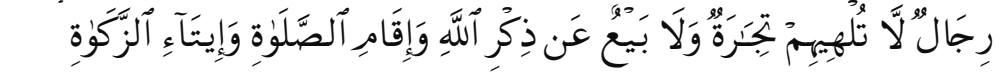 & 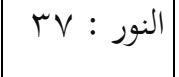 & VY \\
\hline 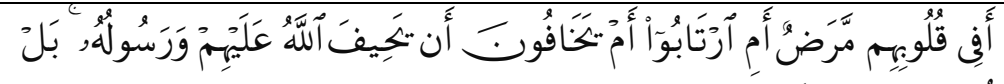 & | النور : ( & VT \\
\hline & $\begin{array}{r}\text { : الشعراء } \\
19\end{array}$ & $V \varepsilon$ \\
\hline & $\begin{array}{r}\text { : الشعراء } \\
\text { الش } 19\end{array}$ & Vo \\
\hline 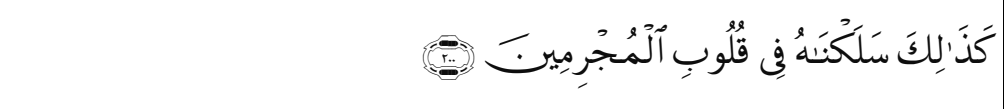 & 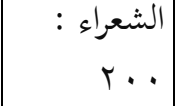 & VT \\
\hline 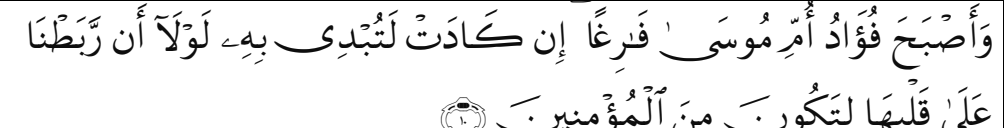 & | القصص : & VV \\
\hline 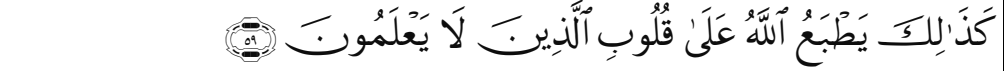 & الروم : 99ه & V^ \\
\hline 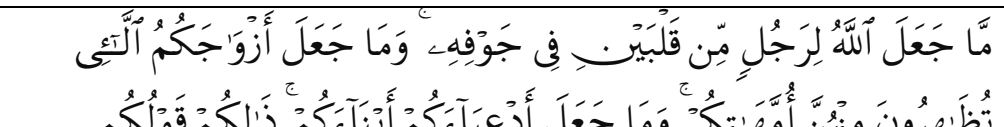 & |الأحزاب : & 19 \\
\hline 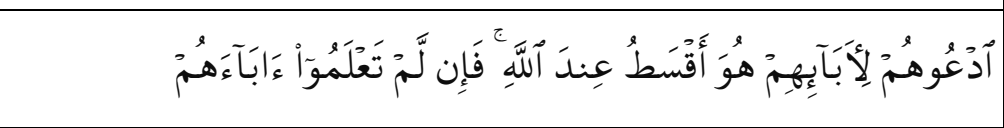 & |الأحزاب : & $\wedge$. \\
\hline
\end{tabular}




\begin{tabular}{|c|c|c|}
\hline ات & سورة و آية & رقم \\
\hline 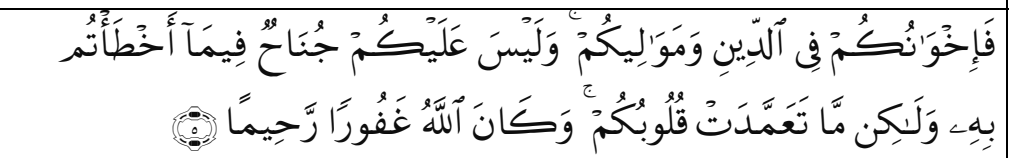 & & \\
\hline 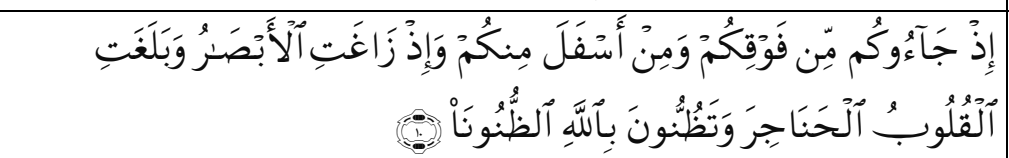 & $\begin{array}{r}\text { : الأحزاب } \\
\text { ال }\end{array}$ & 11 \\
\hline 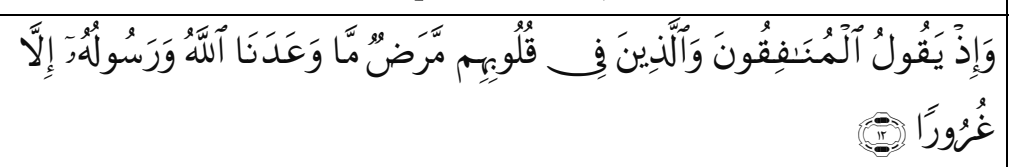 & 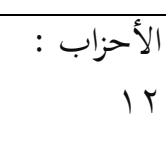 & Nr \\
\hline 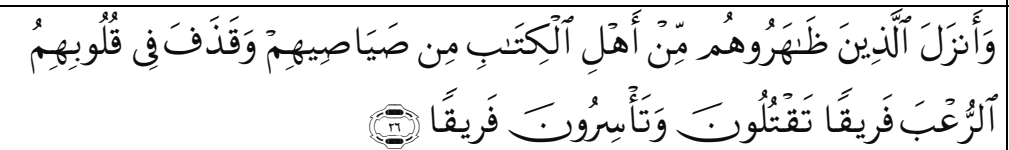 & الأحزاب : & $\Delta r$ \\
\hline 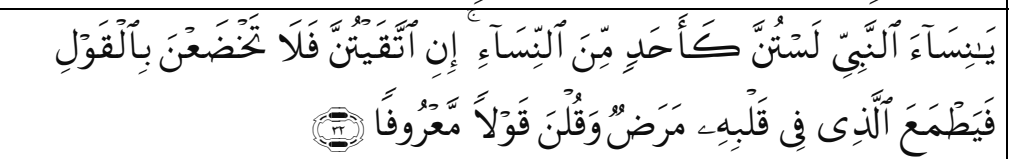 & الأحزاب : & $\Lambda \varepsilon$ \\
\hline 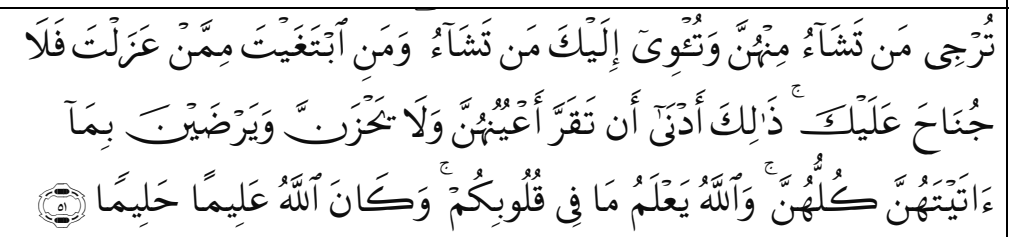 & الأحزاب : & 10 \\
\hline 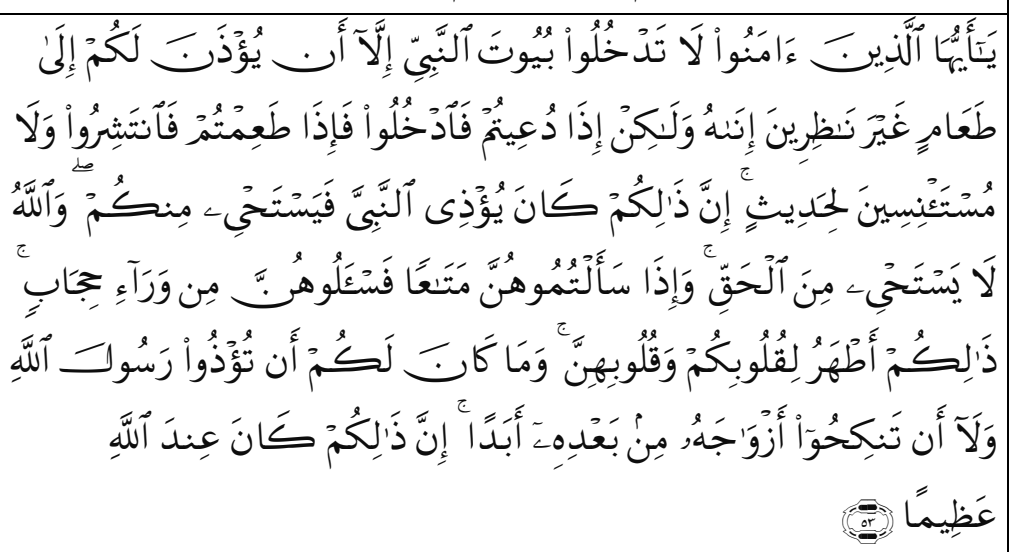 & $\begin{aligned} \text { الأحزاب : } \\
\text { : }\end{aligned}$ & $\Lambda_{7}$ \\
\hline 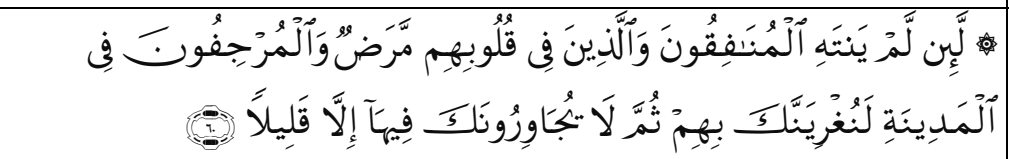 & $\begin{aligned} \text { الأحزاب } \\
\text {. }\end{aligned}$ & $\Lambda V$ \\
\hline 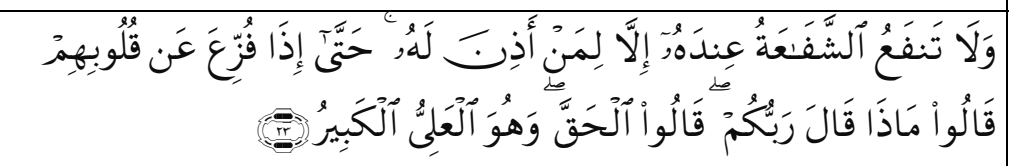 & سبا :Tr & $\wedge \wedge$ \\
\hline
\end{tabular}


Dedih Wahyudin dan Nisa Fitri Ilmiawati

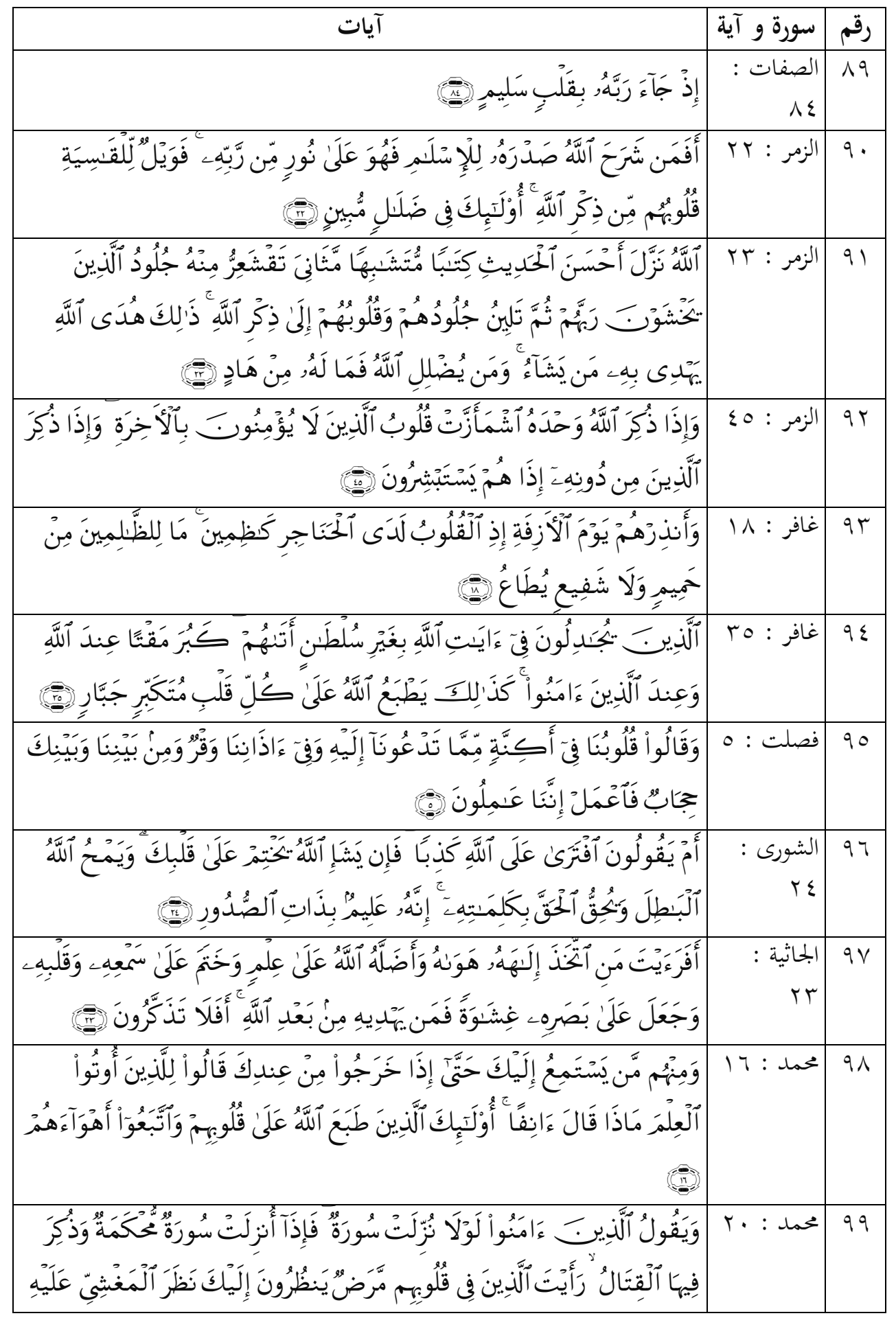




\begin{tabular}{|c|c|c|}
\hline آيات & سورة و آية - مور & رقم \\
\hline & & \\
\hline 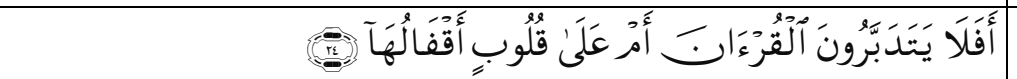 & T & $1 \ldots$ \\
\hline 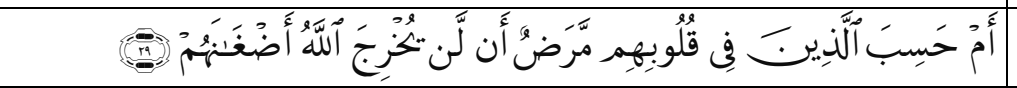 & rq : & 1.1 \\
\hline 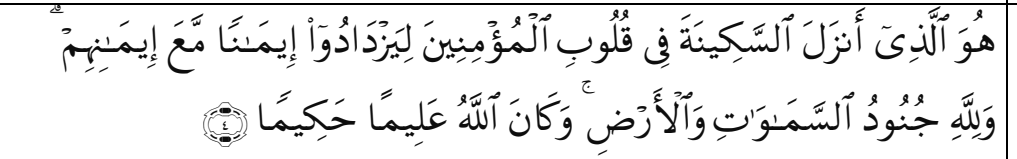 & الفتح : ع & $1 \cdot r$ \\
\hline 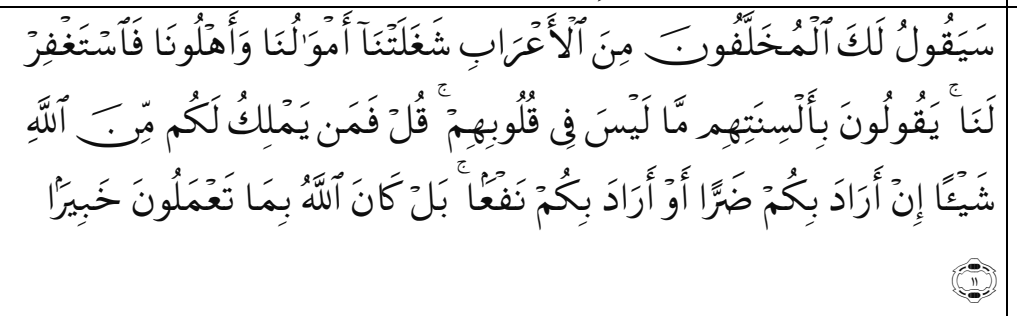 & الفتح : 11 & $1 . r$ \\
\hline 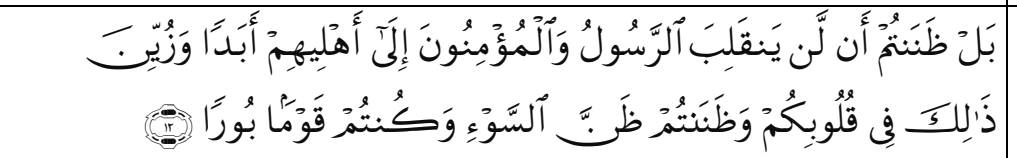 & الفتح : r & $1 \cdot \varepsilon$ \\
\hline 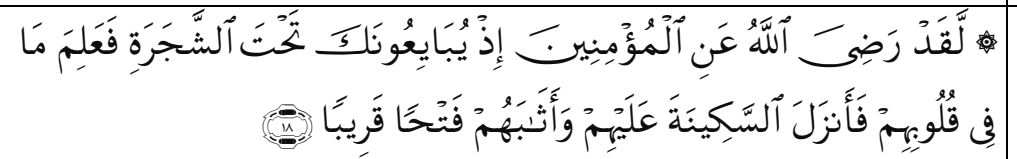 & الفتح : 1 1 & 1.0 \\
\hline 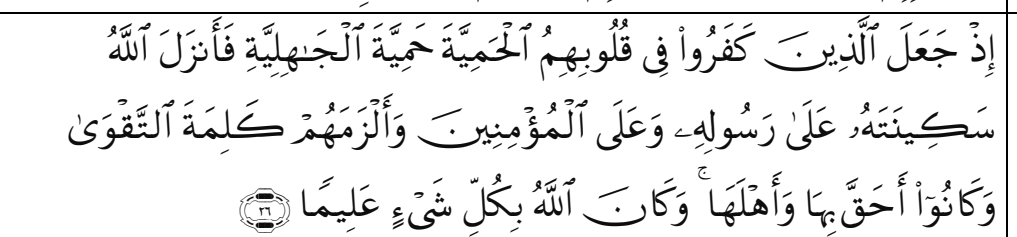 & 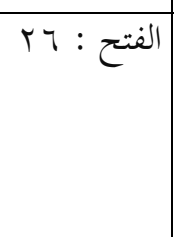 & 1.7 \\
\hline 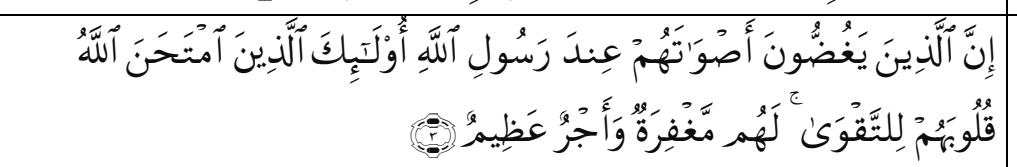 & | الحجرات : & $1 \cdot v$ \\
\hline 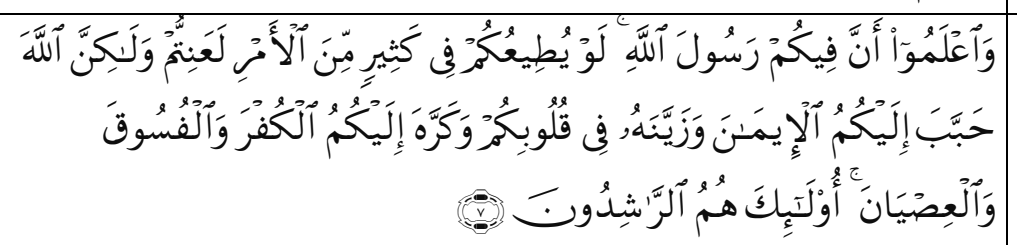 & الحجرات : & $1 \cdot 1$ \\
\hline 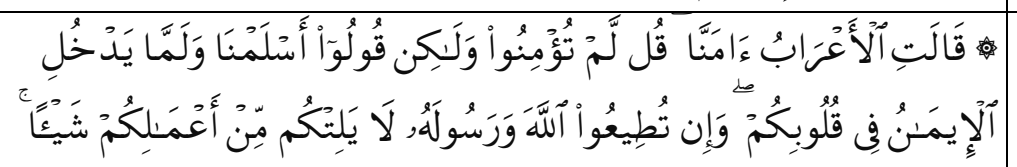 & إل الحجرات : & 1.9 \\
\hline
\end{tabular}


Dedih Wahyudin dan Nisa Fitri Ilmiawati

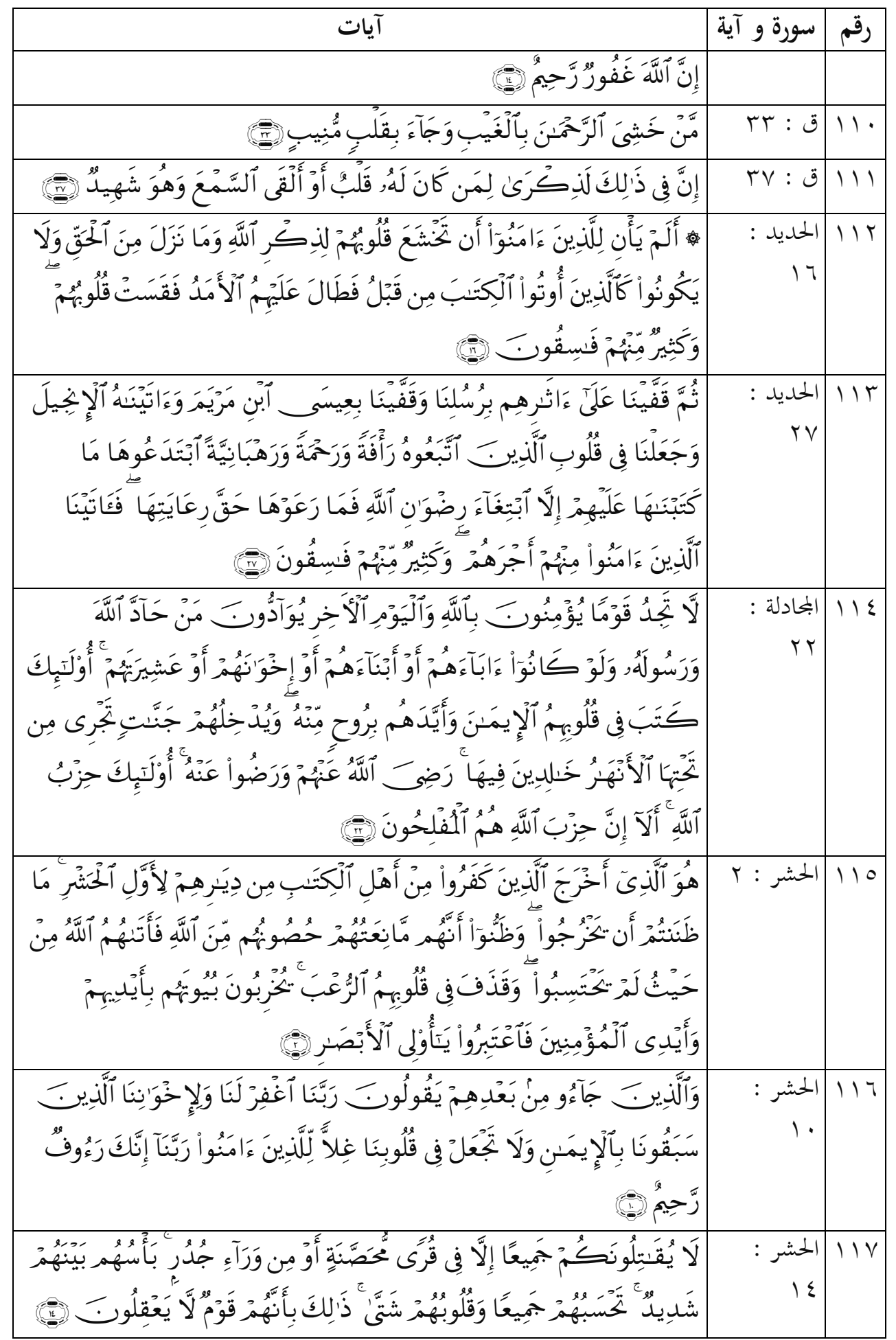




\begin{tabular}{|c|c|c|}
\hline آيات & سورة و آية & رقم \\
\hline 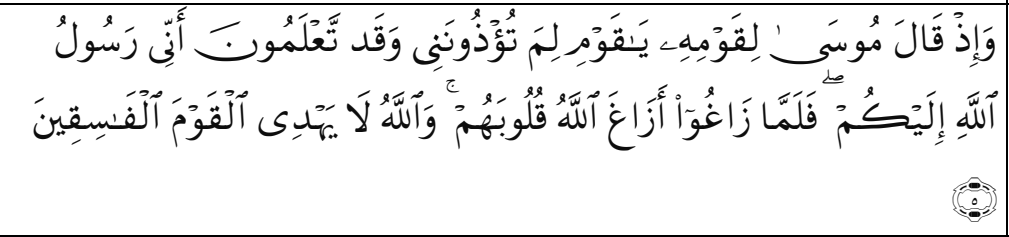 & الصف : 0 & 111 \\
\hline 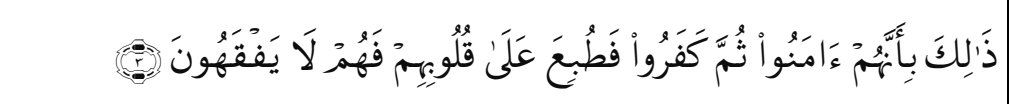 & | المنافقون : & 119 \\
\hline 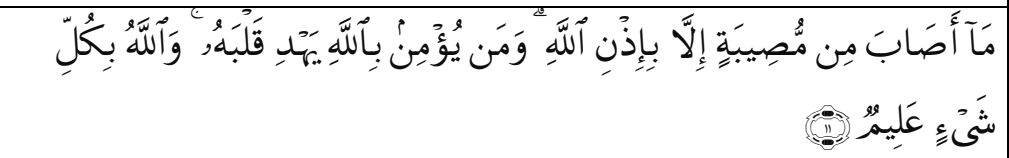 & | التغابن : & Ir. \\
\hline 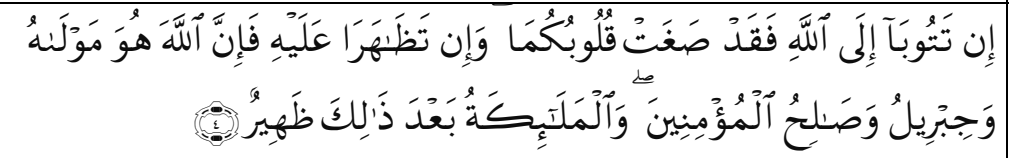 & |التحريم : ع & $|r|$ \\
\hline 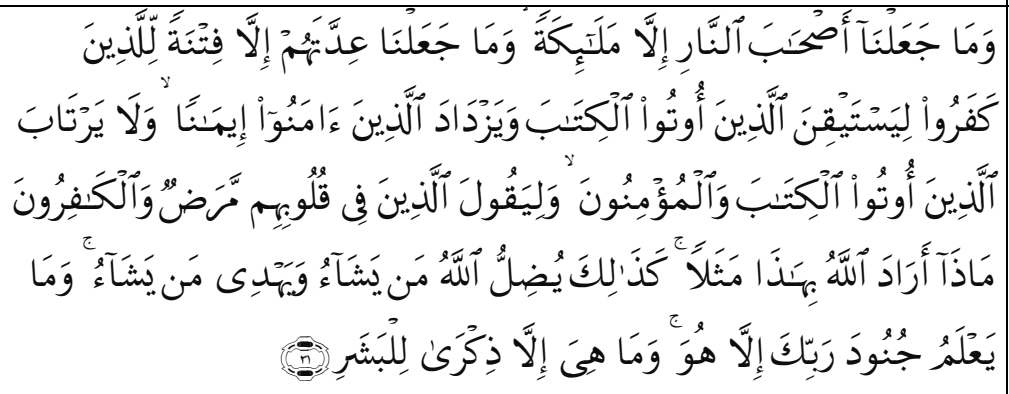 & المدثر : إ & $\mid K T$ \\
\hline 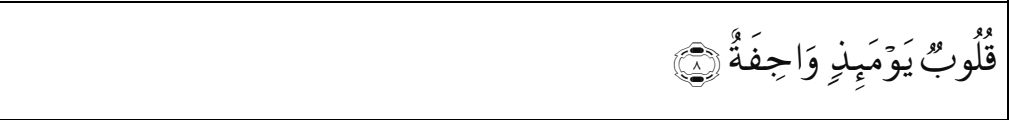 & | النازعات : & ITr \\
\hline 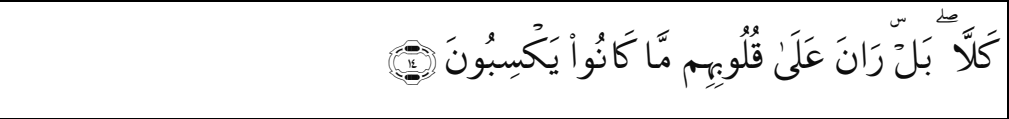 & & $1 T \varepsilon$ \\
\hline
\end{tabular}

تحليل العناصر الدلالية للفظ "القلب" في القرآن الكريم

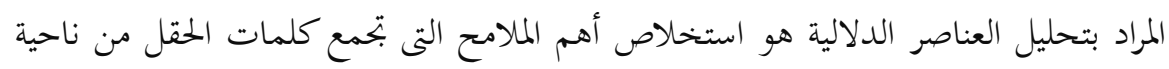

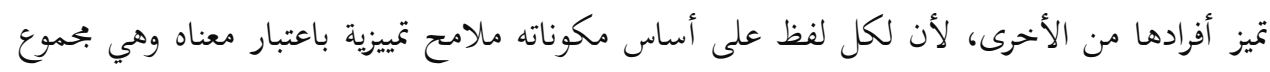
عناصره الدلالية ذات العلاقة المتبادلة. كما قد سبق بيانه، أن لفظ القلب في القرآن الكريع تدل على عدة معادلة المعان، وهي: 1. القلب الذي يدل بمعناه الحقيقى (محل الإحساس والاعتقاد) 
المراد هنا معنى القلب هو اللطيفة الروحية (نفسية) وليس جسديا (المادية). ومن خصائص

$$
\begin{aligned}
& \text { القلب في هذا المعنى المذكورة في القرآن هي: }
\end{aligned}
$$

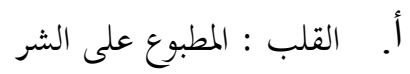

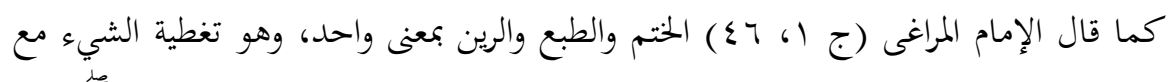

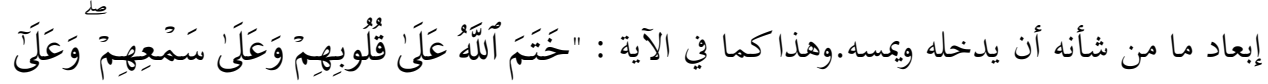

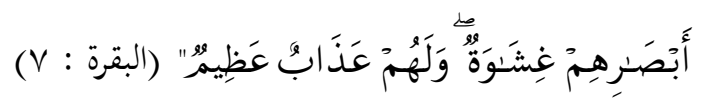

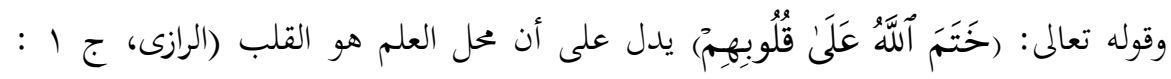

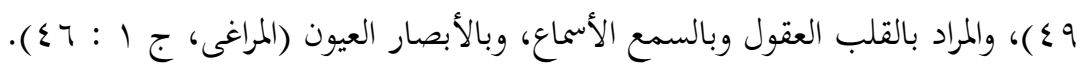

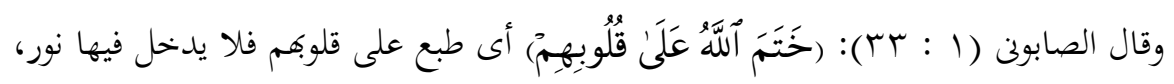

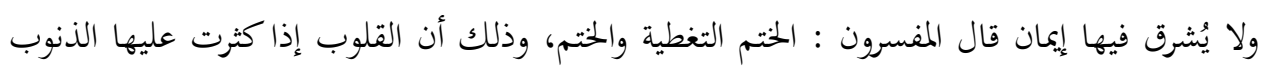

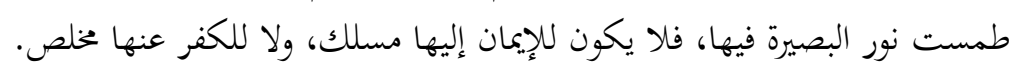

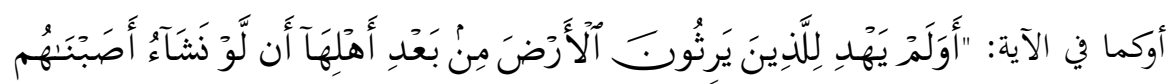

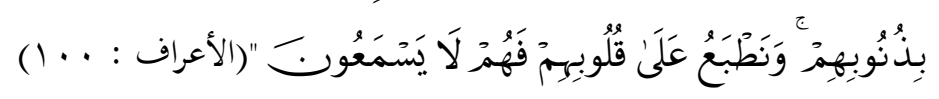

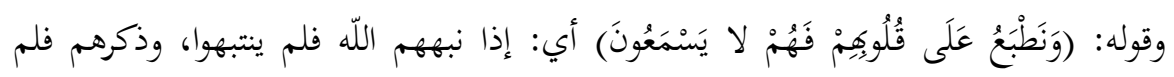

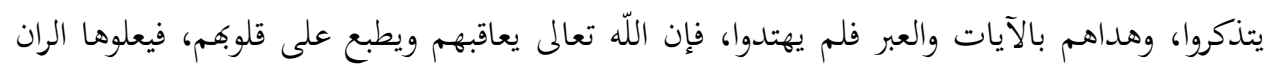

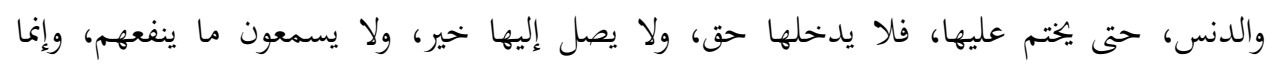

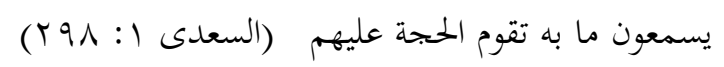

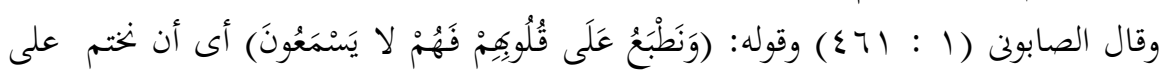

$$
\text { قلوبمم فلا يقبلون موعظة ولا تذكيرا سماع منتفع بكما. }
$$

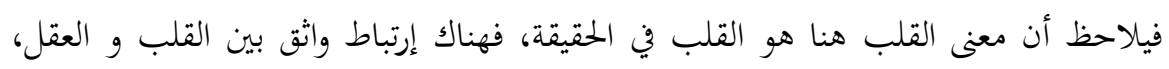
وإرتباط الإثنين معا بالحواس فإما هى مغلقة وإما هى مفتوحة على الحق والنور والهدائ.

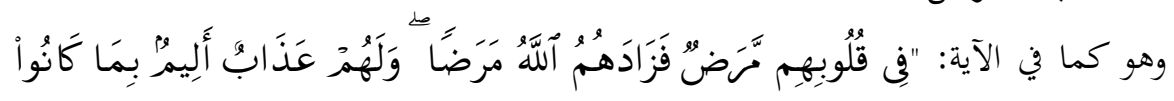

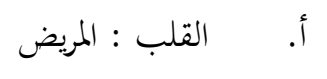

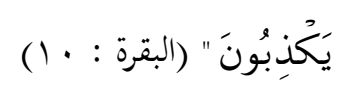




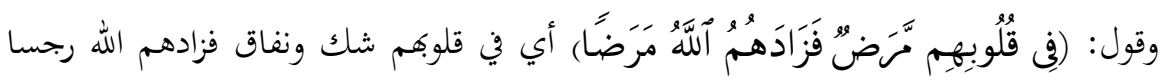

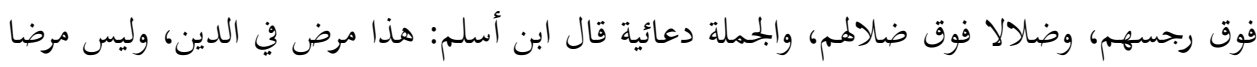

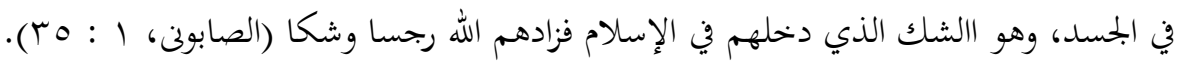

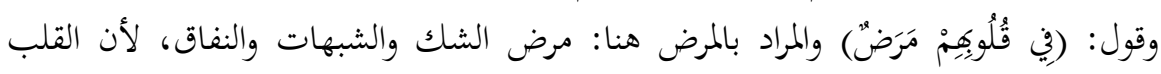

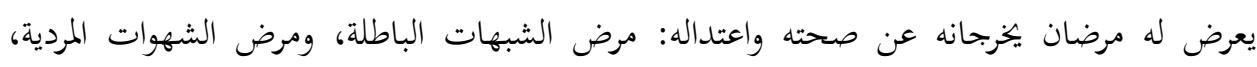

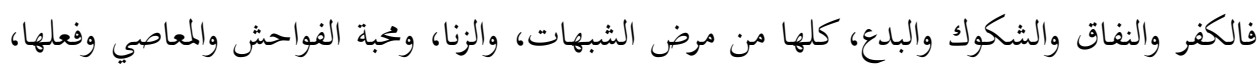

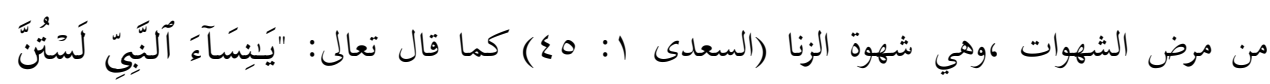

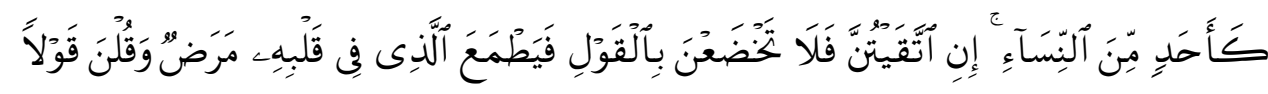

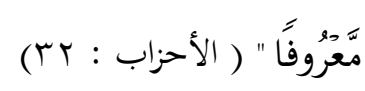

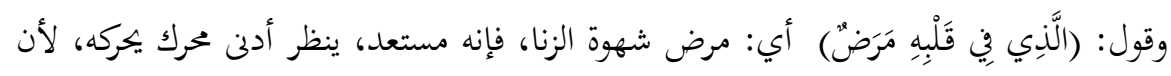

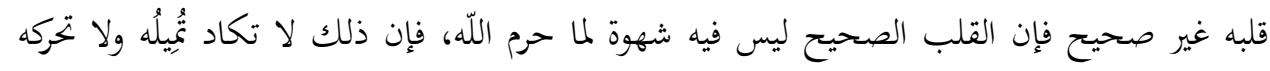

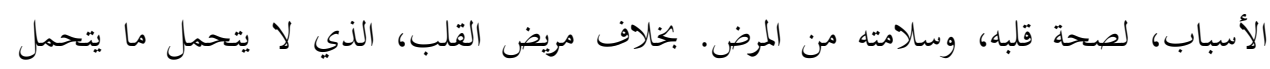

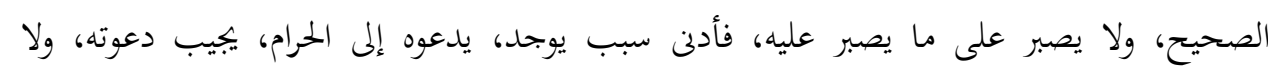

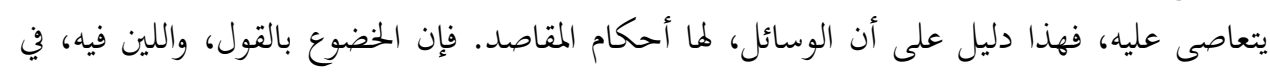

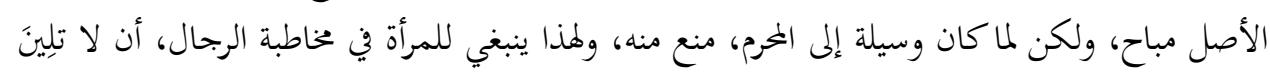

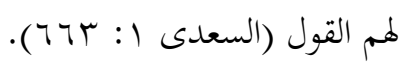

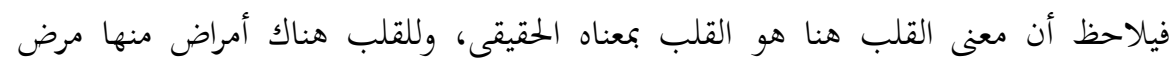

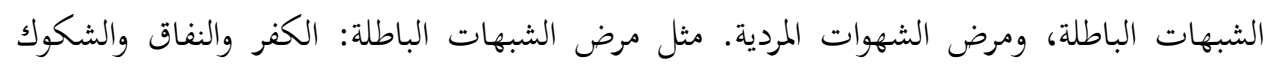

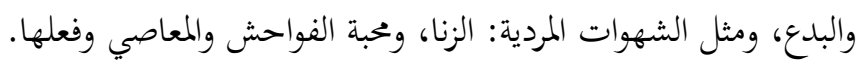

$$
\begin{aligned}
& \text { ج. القلب :من أحواله: قسوة }
\end{aligned}
$$

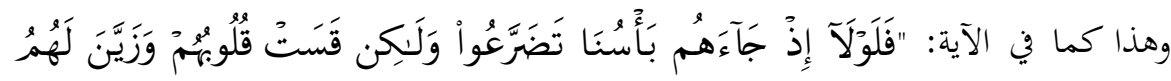

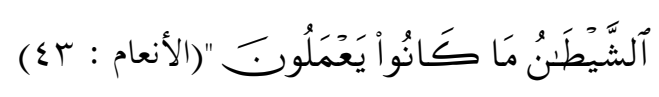

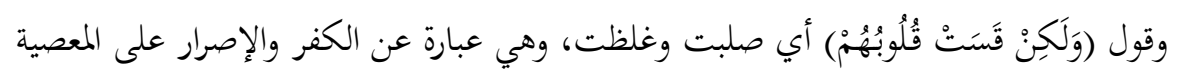

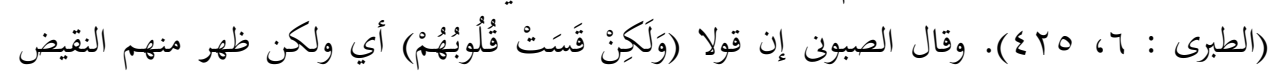

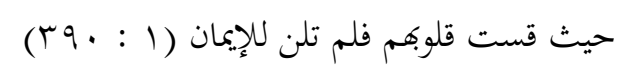

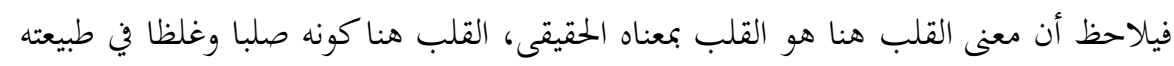
لأنه لم يلن بالإيمان بل إستمرار بالمعصية. 
Dedih Wahyudin dan Nisa Fitri Ilmiawati

$$
\text { د. القلب : محل الإحساس والوجدان }
$$

إن القلب له معنى جانب عاطفى فن الإنسان الذى يمثل المشاعر الوجدانية من حب وحن وكره وخوف وحزن وفرح وغير ذلك، وهذا المعنى كثير في القرآن الكريم. ولفظ القلب التي تدلّ على هذا

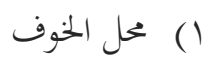

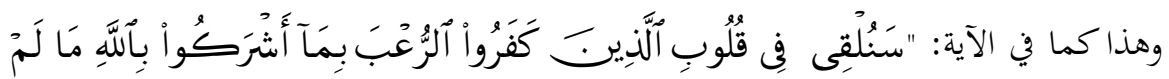

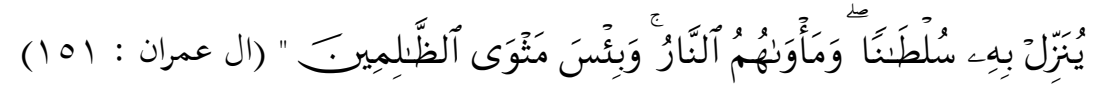

في هذه الآية أنه سبحانه سيحكم في أعداءكم الكافرين سلنه ويلقى في قلوبهم الرعب بسبب

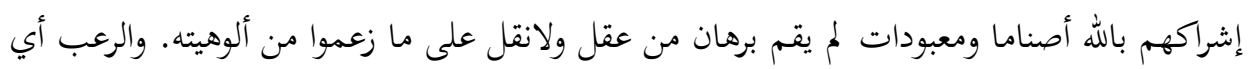

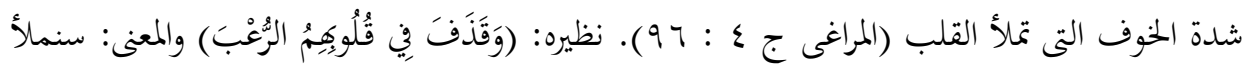

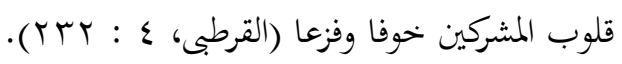

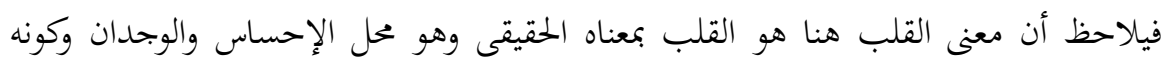

$$
\text { الوجدان الخوف للمشركين. }
$$

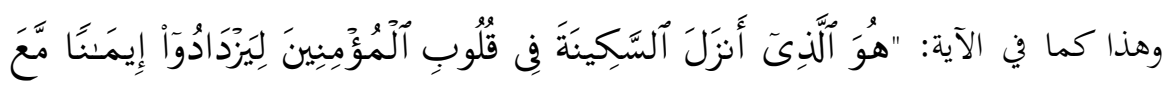

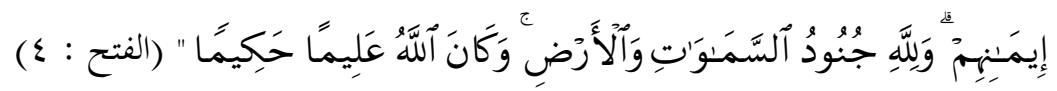

في آية السابقة المراد بالقلب هو محل الإحساس فيه السكينة أو الطمأنينة، قول (هُوَ ألَّلِّىَ

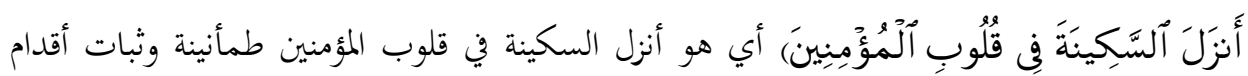

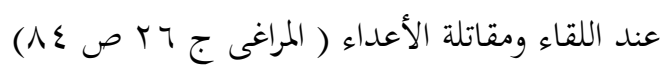

وإلى جانب المشاعر والعواطف التى قد ذكر السابق أن هناك الكثير من المشاعر التي المذكورة في القرآن بشأن حالة القلب مثل الرأفة و الرحمة، اللين، الخشوع وما أشبه ذلك من كل الفضائل والرذائل فمنه يصدر كل شيء. وهو الذي يعبر عن حقيقة الإنسان وعن خفاياه ونواياه. هـ. القلب : محلّ الإعتقاد

$$
\text { ( ) محلّ الإيمان }
$$

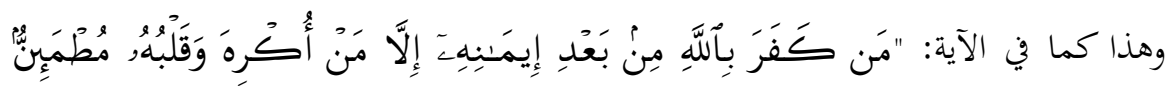

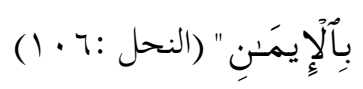




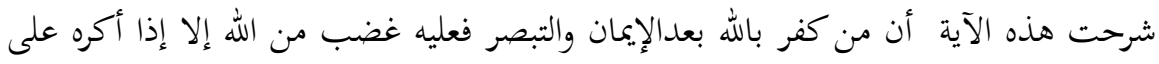

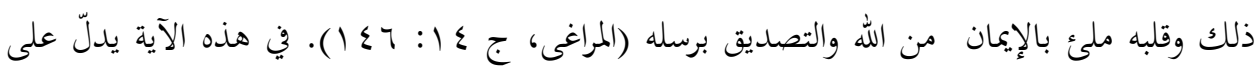
معنى القلب هو محل الإعتقاد هو الإيمان التى تملأ في القلب. (r) محلّ الكفر

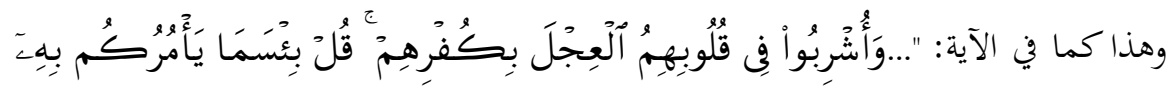

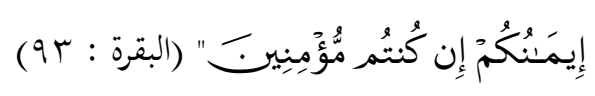

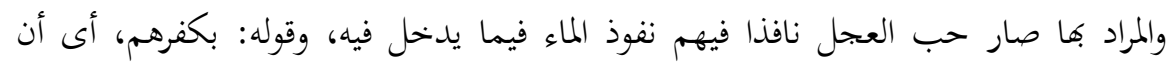

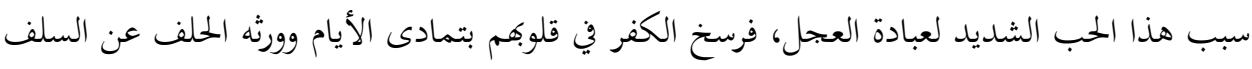

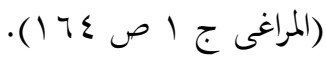
فالياحظ من الآية السابقة يظهر أن محل الكفر هو قلب ينفذ فيه.

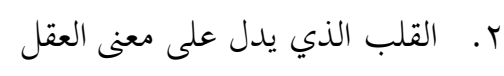

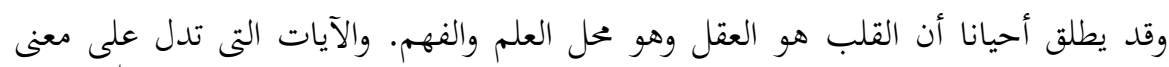

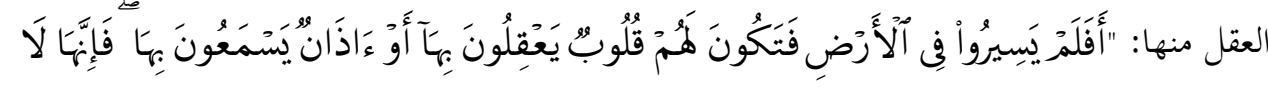

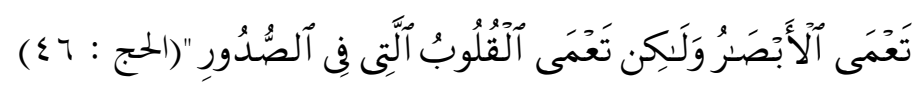

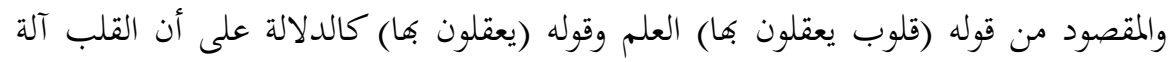

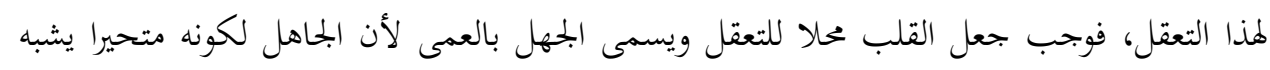

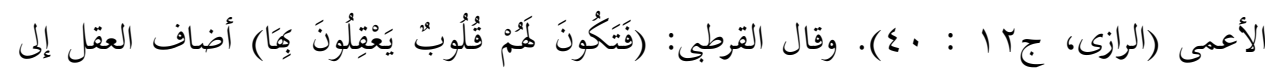

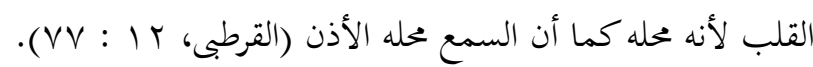

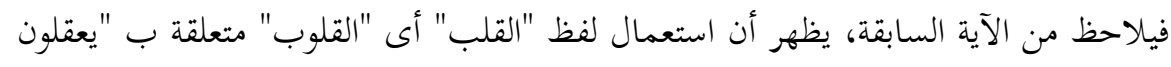

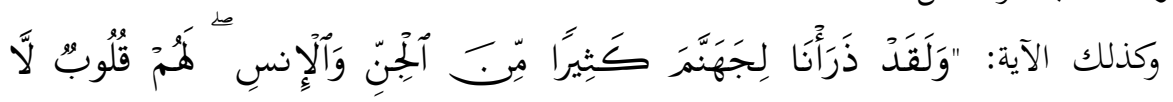

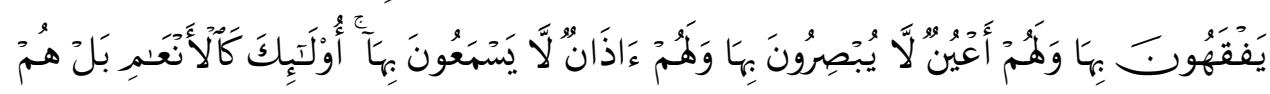

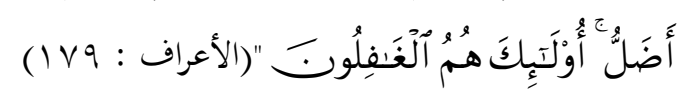

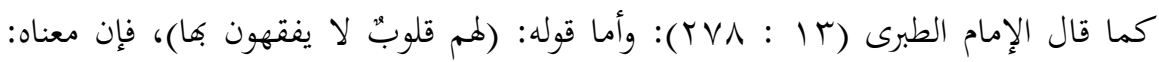

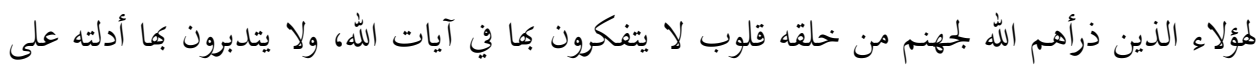

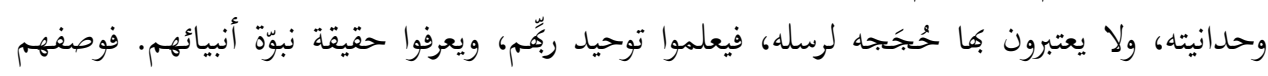


ربُُنا جل ثناؤه بأفهم: "لا يفقهون بها"، لإعراضهم عن الحق وتركهم تدبُّر صحة [نبوّة] الرسل، وبُطُول

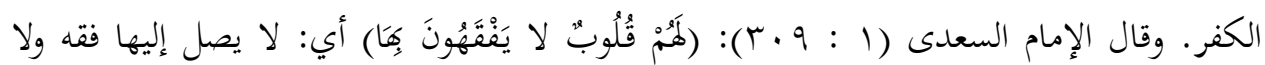
علم، إلا بحرد قيام الحجة. وقال الامام المعال

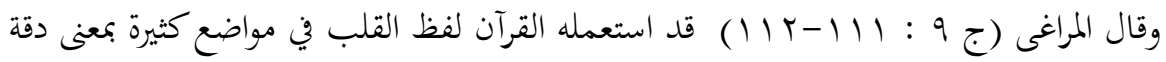

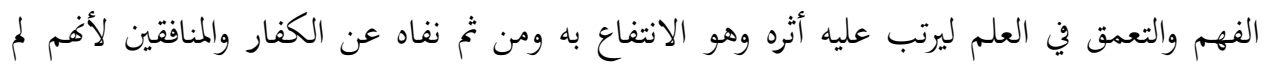

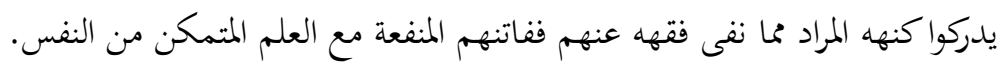

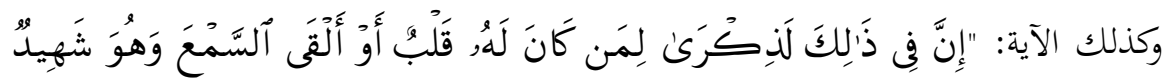
( $($ ( )

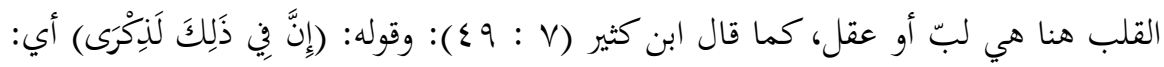

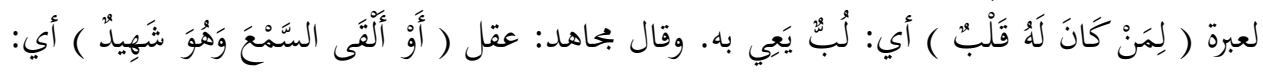

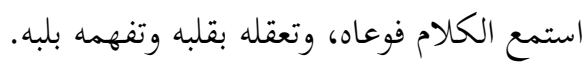

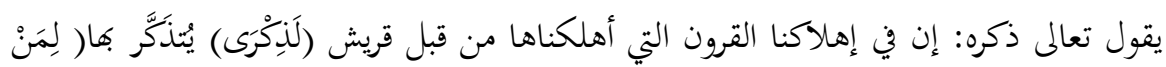

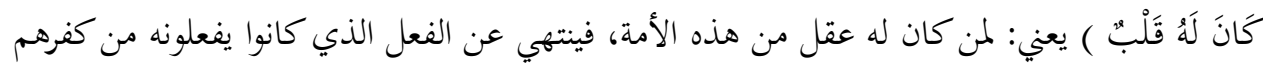

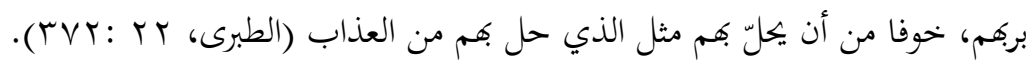

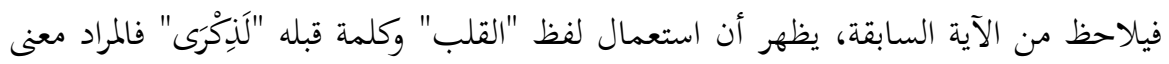
القلب هنا هو العقل.

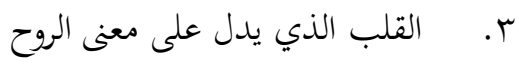

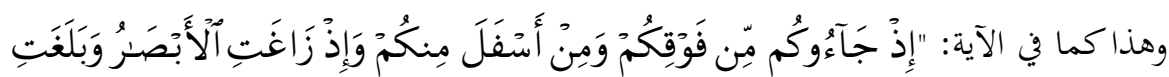

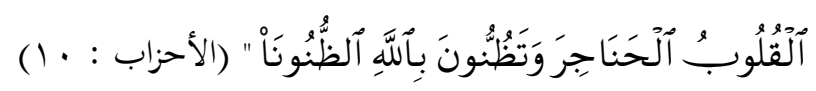

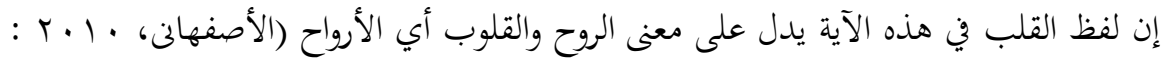
(r).

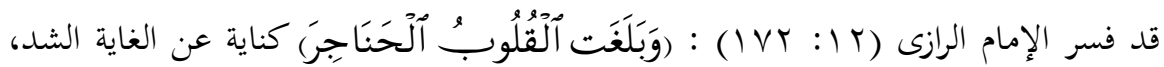

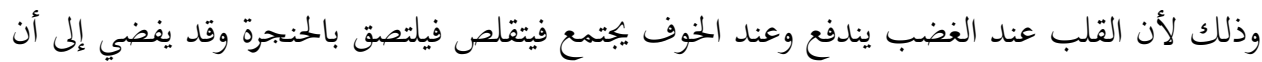

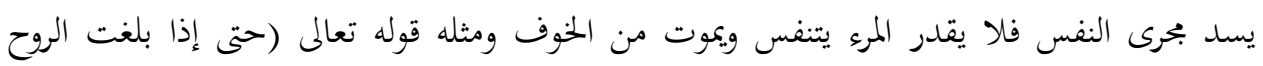

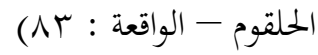
ويفهم في الآية السابقة أن القلب هو الروح الذي بلغ الحلقوم بسبب شدة الخوف. 
من البيان السابق، يعرف أن لفظ القلب في القرآن ذكر ب ا I مرة في بع سورة. وهو سياقيا وضع لثلاثة معان وهي: (1) القلب بمعنى محل الإحساس والاعتقاد وهو اللطيفة الربانية، هذا المعنى

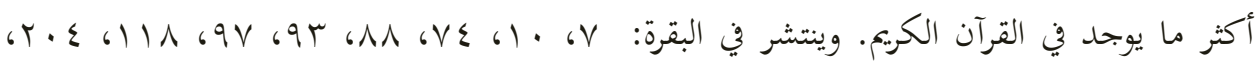

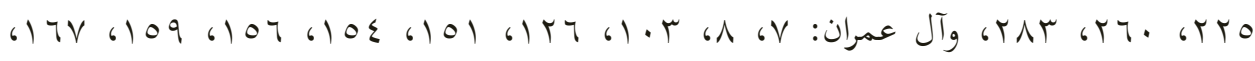

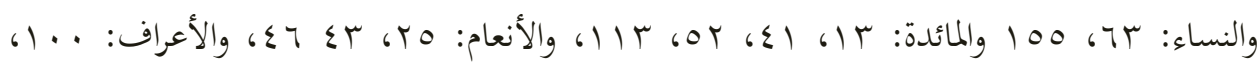

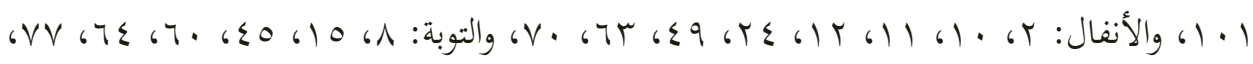
A V

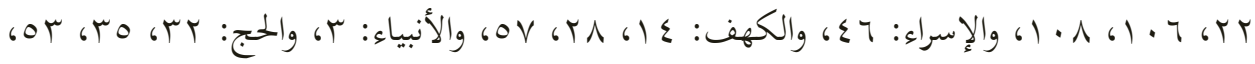

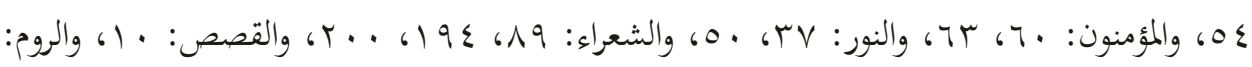

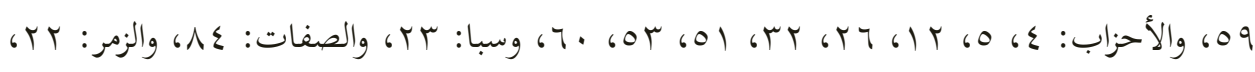
r

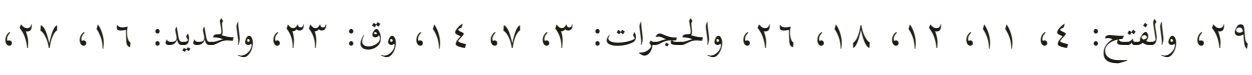

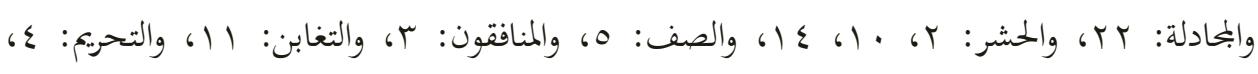

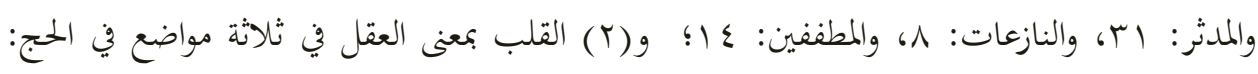

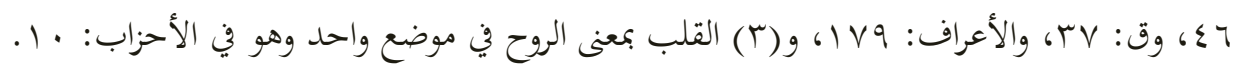

\section{التضمين التربوي لمعانى "القلب" في القرآن الكريم"}

التضمين التربوي هو فكرة مفيدة في عملية التربية وسيلة للوصول إلى الغران الغاية النهائية في التربية التربية

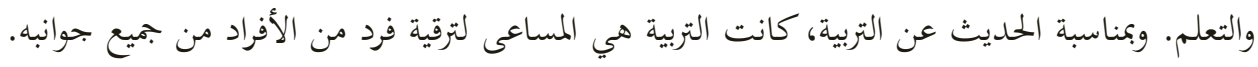

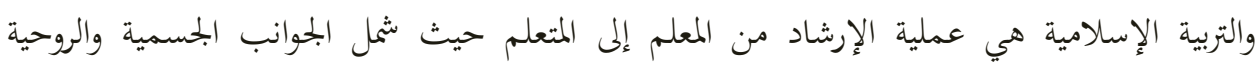

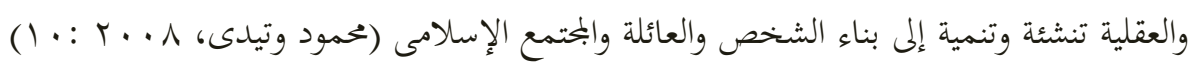

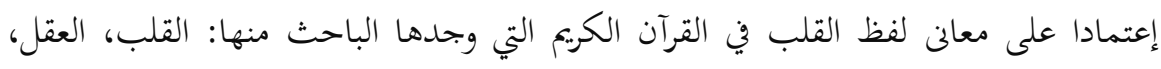

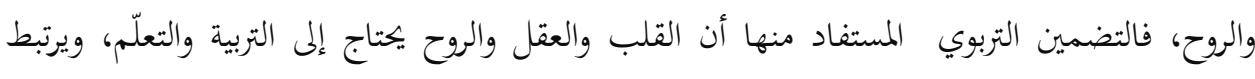

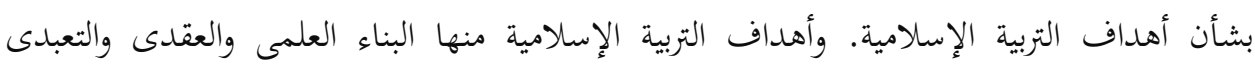

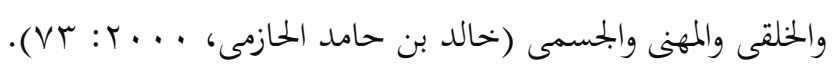

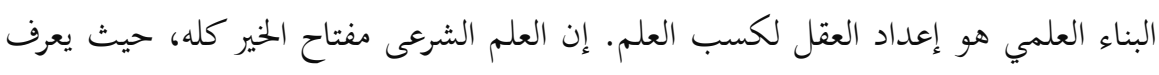

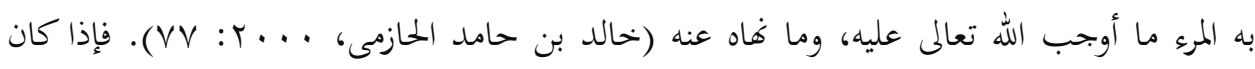

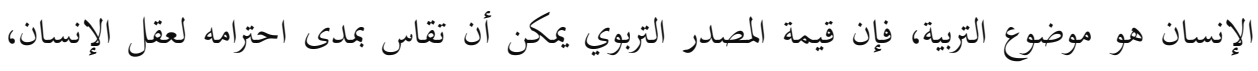




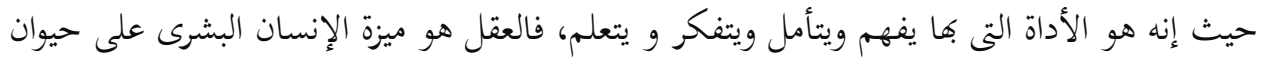

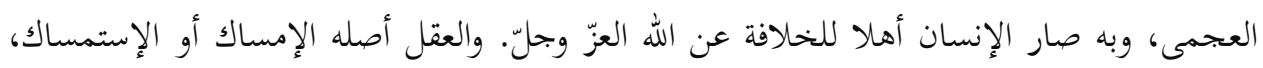

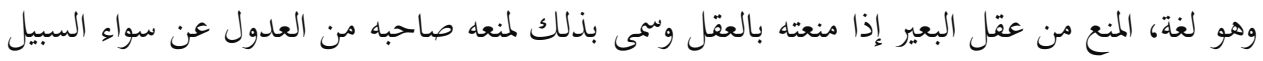

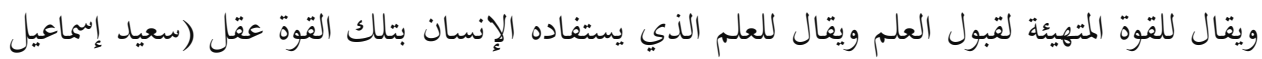

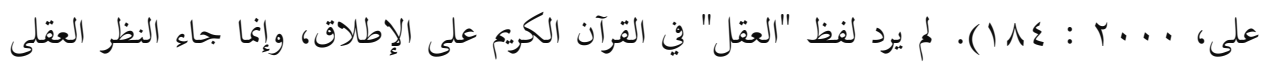

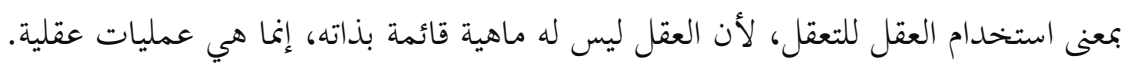

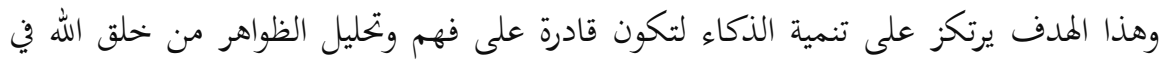

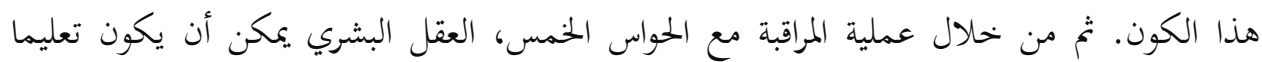

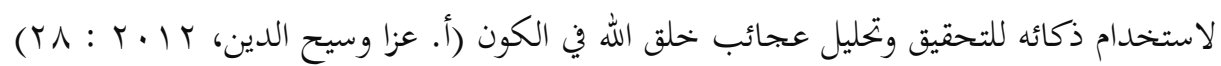

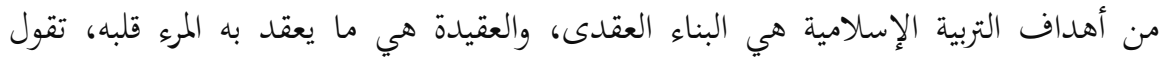

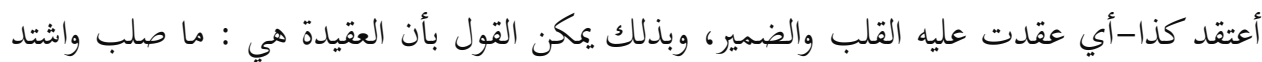

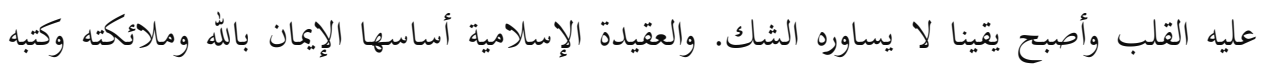

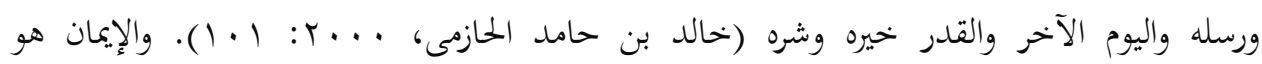

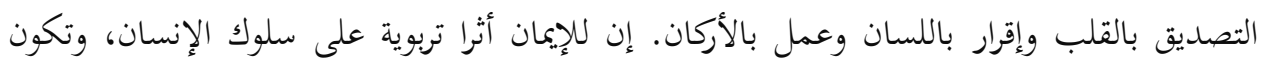

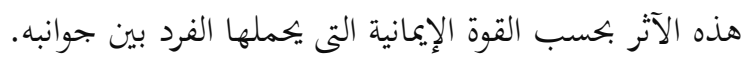

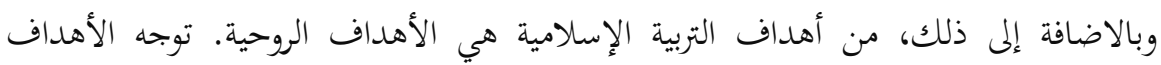

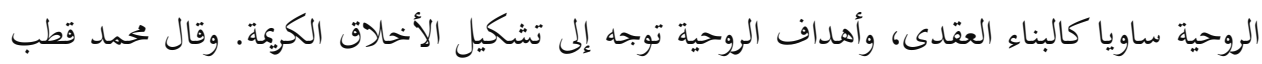
(199T) وكل عمل وكل فكرة وكل شعور. الروح تلك الطاقة المجهولة التى لانعرف كنهها ولا طريقة عملها هي وسيلتنا للاتصال بالله. وفي التربية الروحية يستخدم القلب وسيلة شتى فهو:

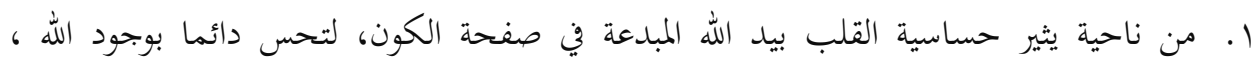

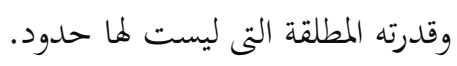
r. من ناحية يثير حساسية القلب برقابة الله الدائمة عليه. فهو مع الإنسان أينما كان، وهو مطلع على فؤاده، عالم بكل أسراره، وبما هو أخفى من الأسرار.

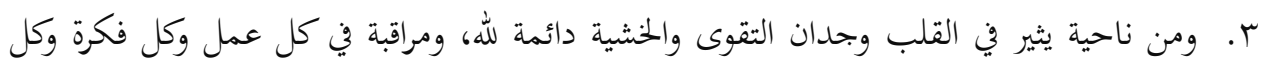
شعور.

ع. ومن ناحية يثير فيه الحب لله، والتطلع الدائم إلى رضاه.

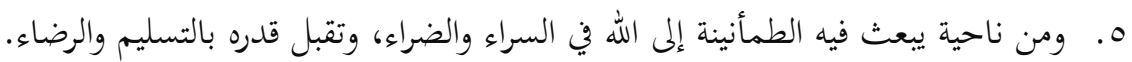




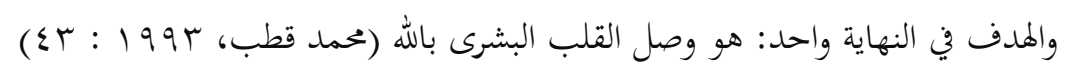

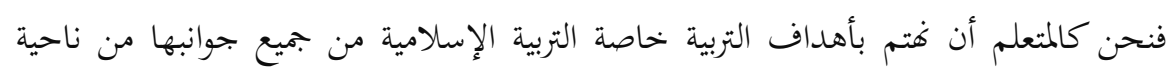

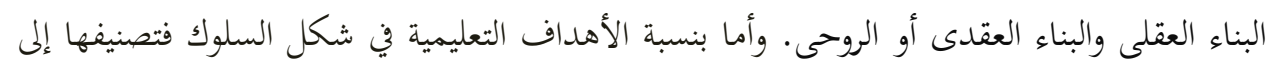

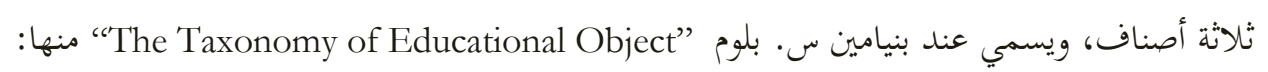

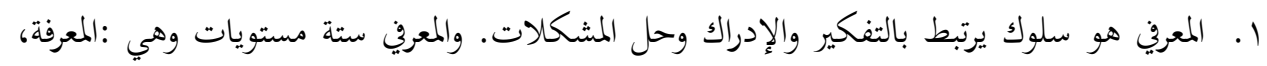

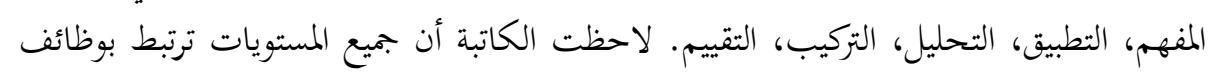

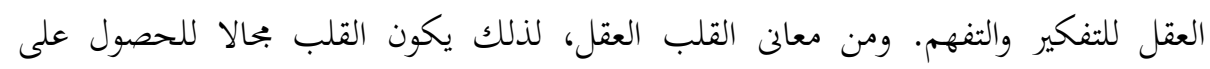

الجوانب المعرفية.

r. الوجدانية هي التي ترتبط على المواقف والقيم، ومشاعر التقدير والتكيف الاجتماعي أو حافز

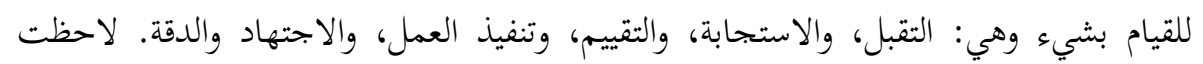

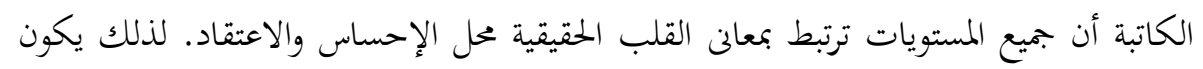
القلب بحالا للحصول على الجوانب الوجدانية.

النتيجة

لقد اختلف علماء التربية عن معنى القلب في القرآن الكريم. بعضهم يرى أنه وضع لمعنى العقل

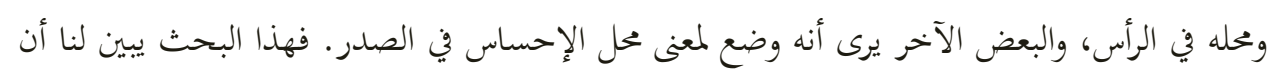

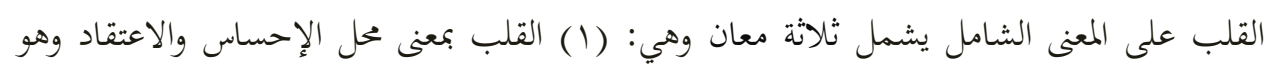

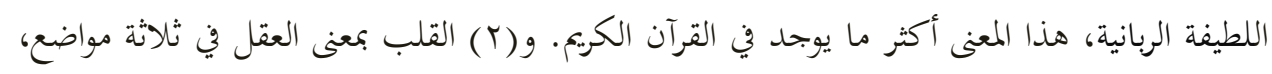

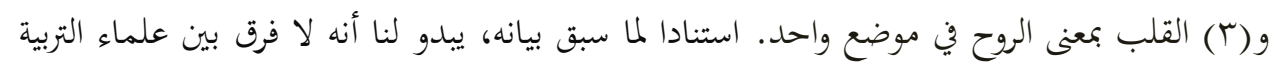

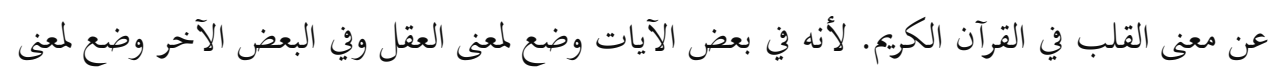
محل الاحساس والاعتقاد.

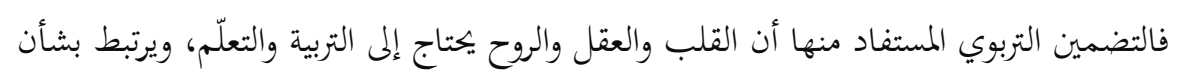

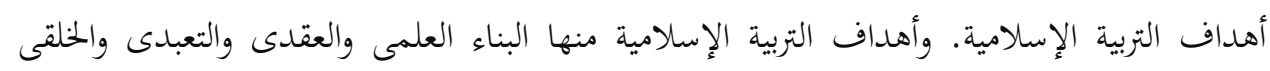

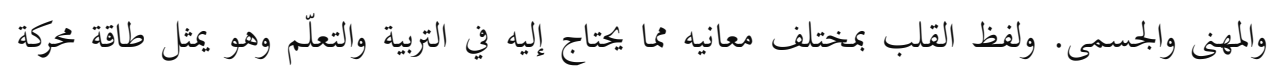

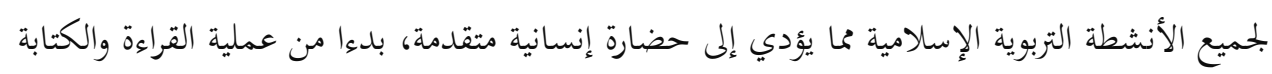

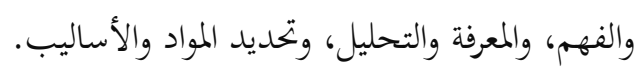




$$
\text { المراجع }
$$

أبو حامد محمد بن محمد الغزالي، دون سنة، إحياء علوم الدين، الجزء الثالث، دار إحياء الكتب

$$
\text { العربية. }
$$

أحمد مختار عمر، ب99 19، علم الدلالة، الطبعة الثالثة. علام الكتب: القاهرة.

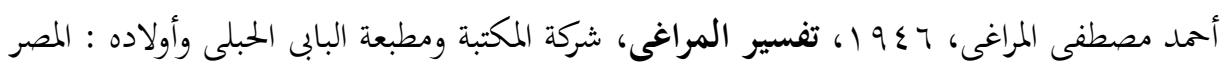
ابن كثير، إسماعيل بن عمر القرشي الدمشقي 1999، 199، تفسير ابن كثير، دار طيبة.

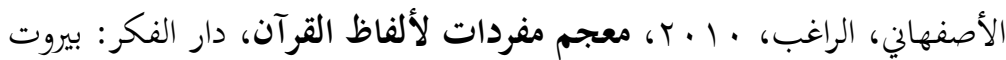

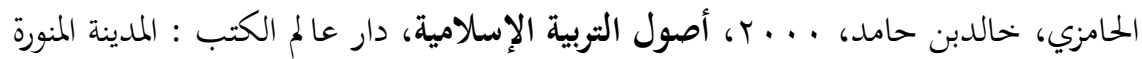

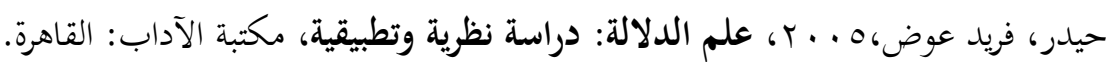

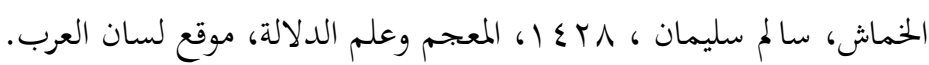

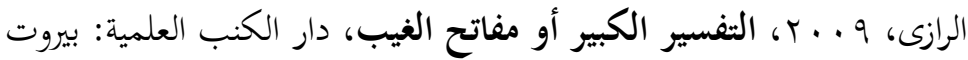

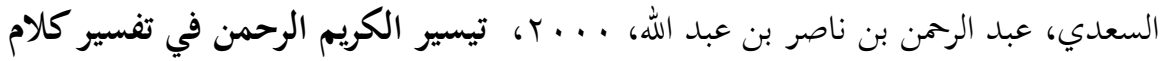

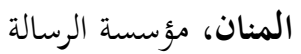

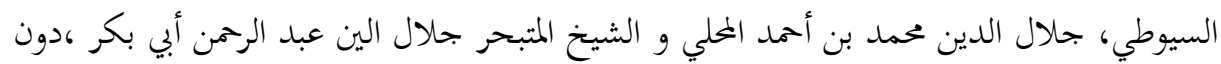
سنة، تفسير القرآن الكريوم للإمام الجليلين، طه فترا: سمارانج.

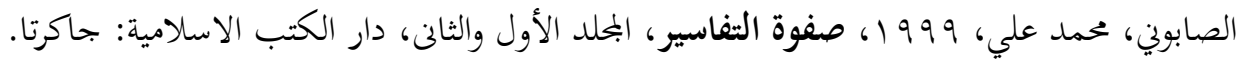

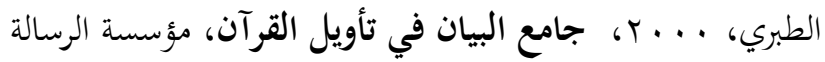

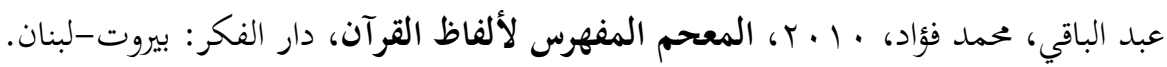

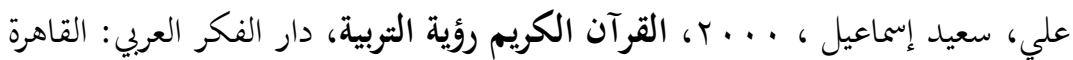

$$
\text { قطب، محمد ،بو9 القب، الجامع لأحكام القرآن، دار الكتب العلمجية، بيروت: لبنان. }
$$

Anwar, Rosihon, 2008. Ulum Al-Quran. Bandung : Pustaka Setia

Izzan, Ahmad dan Saehuddin, 2012. Tafsir Ayat-Ayat Pendidikan, Banten: Putaka Aufa Media 